\title{
Araç Rotalama Probleminin Genetik Algoritma ile Çözümü ${ }^{1}$
}

\author{
Solution of Vehicle Routing Problem with Genetic Algorithm
}

\author{
Ebru OKUR² - Dr. Öğr. Üyesi Mahmut ATLAS
}

Başvuru Tarihi: 27.07.2020

Kabul Tarihi: 23.09.2020

Makale Türü: Araştırma Makalesi

\section{Öz}

Bu çalışmada, çözülmesi zor problemler sınıfında yer alan araç rotalama problemi ele alınmıştır. Araç rotalama problemi kısaca, müşteri taleplerini karşılayacak ürün dağıtımına ait optimum rotaların tasarlanması problemidir. Toplam kat edilen mesafenin en küçüklenmesi problemin temel amacını oluşturmaktadır. Günümüz iş hayatında ürün dağıtım maliyetleri toplam lojistik maliyetlerinin önemli bir kısmını oluşturmaktadır. Bu çalışmada meta-sezgisel çözüm tekniklerinden birisi olan genetik algoritma kullanılarak Eskişehir Halk Ekmek A.Ş.'nin tüm müşteri taleplerini karşılayacak araç rota mesafesini iyileştirmek amaçlanmaktadır. Bu amaçla, genetik algoritmanın hem zor ve büyük ölçekli problemleri etkin bir şekilde çözebilmesi, hem de kısa sürede optimuma yakın çözümler üretebilmesi özelliğinden yararlanılarak Eskişehir Halk Ekmek A.Ş.'nin dağıtım araçlarının, satış büfelerine en kısa mesafeden rota hesaplamasına optimum çözüm aranmıştır ve mevcut durum ile karşılaştırma yapılmıştır. Ekmekler, tek bir üretim tesisinde üretilerek 51 adet satış büfesi aracılı̆̆ıyla halka ulaştırılmaktadır. Üretim tesisinin satış büfelerine olan uzaklıkları "Google Maps" üzerindeki konumlarından sağlanmıştır. Ele alınan problem için genetik algoritma $2000 \mathrm{kez}$ çalıştırılmıştır ve yaklaşık olarak 25 saniye (sn) gibi kısa bir sürede sonuca ulaşılmıştır. Genetik algoritma ile belirlenen araç rotalama işlemi sonucunda Eskişehir Halk Ekmek Iş̧letmesi'nin mevcut olarak kullandığı rotasyon iyileştirilerek daha iyi bir sonuç elde edilmiştir. Çalışma öncesinde, Eskişehir Halk Ekmek Iş̧letmesi rotalarının oluşturulmasında 17 yillık tecrübesinden yararlanarak 3 aracın toplam kat ettiği mesafeyi 236,54 $\mathrm{km}$ olarak belirlediği görülmektedir. Genetik algoritma ile hesaplama sonucunda ise 3 aracin toplam kat ettiği mesafe 210,24 km olarak hesaplanmıştır. Bu durumda, günlük olarak hesaplanan değerde 26,3 km'lik bir iyileşme sağlanmaktadır. Aylık olarak düşünüldü̈̆̈̈nde, bir ay için yaklaşık olarak $790 \mathrm{~km}$ 'lik bir iyileşme sağlamaktadır. Maliyet bazında bakıldığında, kullanılan araçlar şehir içinde gidilen her km'de ortalama 1,6 TL/lt yakıt harcamaktadır ve aylik olarak düşünüldü̈̆ünde işletme için 1.264 TL'lik bir yakıt tasarrufu ile maliyette azalma sağlanmaktadır. Bu çalışma sonucunda işletmeye ait 51 adet satış büfesi için tüm talepleri karşılayacak bir rotasyon oluşturularak araçlarının hem zamandan tasarruf etmesini hem de maliyetin düşürülmesini sağlayan bir çözüm sunulmuştur.

Anahtar Kelimeler: Genetik Algoritma, Araç Rotalama Problemi, Meta-Sezgisel Teknikler

\footnotetext{
Bu çalışma 2019 yılında Anadolu Üniversitesi Sosyal Bilimler Enstitüsü İşletme ABD Sayısal Yöntemler Bilim Dalında savunulmuş olan yüksek lisans tezinden türetilmiştir.

${ }^{2}$ Anadolu Üniversitesi Sosyal Bilimler Enstitüsü Sayısal Yöntemler Bilim Dalı Doktora Öğrencisi, ebruokur@anadolu.edu.tr, ORCID: 00000003-2305-539X

${ }^{3}$ Anadolu Üniversitesi, İIBF, İșletme Bölümü, matlas@anadolu.edu.tr, ORCID: 0000-0002-0242-569X
} 


\section{Abstract}

In this study, vehicle routing problem which is in the class of hard to solve problems is addressed. The vehicle routing problem is, in short, the problem of designing optimal routes for product distribution to meet customer demands. The main objective of the problem is to minimize the total distance traveled. In today's business world, product distribution costs constitute an important part of total logistics costs. In this study, it is aimed to improve vehicle route distance to meet all customer demands of Eskişehir Public Bread Company Company using genetic algorithm, which is one of the meta-heuristic solution techniques. For this purpose, by using the genetic algorithm to solve difficult and large-scale problems effectively and to produce solutions that are close to optimum in a short time, Eskişehir Public Bread Company distribution vehicles are searched for the optimum solution for the route calculation to the sales points from the shortest distance and a comparison was made with the current situation. Breads are produced in a single production center and delivered to the public through 51 sales buffets. The distances of the production facility from the sales buffets are determined from their location on "Google Maps". The genetic algorithm was run 2000 times for the problem under consideration, and the result was reached in a short period of approximately 25 seconds (sec). As a result of the vehicle routing process determined by the genetic algorithm, a better result was obtained by improving the rotation used by Eskişehir Public Bakery Company. Before the study, it is seen that Eskişehir Public Bread Company determined the total distance traveled by 3 vehicles as $236.54 \mathrm{~km}$, benefiting from 17 years of experience in the creation of routes. Considered on a monthly basis, it provides an improvement of approximately $790 \mathrm{~km}$ for a month. On the basis of cost, the vehicles used consume $1.6 \mathrm{TL} / \mathrm{lt}$ of fuel per km traveled in the city, and when considered monthly, a reduction in cost is achieved with a fuel saving of $1.264 \mathrm{TL}$ for the business. As a result of this study, a solution was created to meet all demands for 51 sales buffets belonging to the enterprise, thus saving both time and cost for their vehicles.

Keywords: Genetic Algorithm, Vehicle Routing Problem, Meta-Heuristic Techniques

\section{Giriş}

Günümüzde Lojistiğin alt konusu olan araç rotalama problemi, toplam dağıtım maliyetinin önemli bir bölümünü oluşturmaktadır. Çalışmanın “Araç Rotalama Problemi” başlıklı ilk bölümünde, araç rotalama problemi tanıtılmıştır.

Genetik algoritmalar çözümü zor problemler için geliştirilmiş popülasyon temelli bir metasezgiseldir. Probleme ait değişkenler, kromozom vektörlerinin genlerinde temsil edilmektedir. Seçim, çaprazlama ve mutasyon olarak adlandırılan genetik operatörler, iterasyonlar boyunca kromozomlarda birtakım değişiklikler yapmakta ve en iyi sonucu verecek çözüm seti aranmaktadır. Seçim, daha iyi çözümlerin sonraki iterasyonlar için yaşama şansını arttıran, daha kötü sonuçları eleyen operatördür. Çaprazlamada kromozomlar arası bilgi değişimi yapılarak, daha iyi bireyler elde edilmeye çalışılır. Mutasyon işlemi, önceki işlemlerde kaybedilen yararlı genlerin kurtarılması için tasarlanmıştır. Farklı problemler için kullanılan 
farklı genetik operatör çeşitleri bulunmaktadır. Araç rotalama probleminin çözümünde optimum rotaların belirlenebilmesi için birden çok teknik vardır. Ancak her durumda en iyi sonucu verebilecek kesin bir çözüm tekniği ortaya konulamamıştır. Bu sebeple, kesin tekniklerin yetersiz kaldığg durumlar için sezgisel ve meta-sezgisel çözüm teknikleri geliştirilmiştir.

Çalışmanın "Genetik Algoritma” başlıklı ikinci bölümünde, araç rotalama problemi çözüm yaklaşımlarından meta-sezgisel çözüm teknikleri sınıfında yer alan genetik algoritmanın detaylarına yer verilmiştir.

Genetik algoritma, evrim sürecinden ilham alınarak oluşturulmuş olup, en iyinin hayatta kalma temeline dayanmaktadır. Çalışmanın üçüncü bölümünde ise, uygulama çalışması yer almaktadır.

\section{Araç Rotalama Problemi}

Günümüz üreticilerinin temel amaçlarından birisi de ürünlerinin talep noktalarına en kısa yoldan ve en az maliyetle ulaştırılmasıdır. Araç rotalama problemi, bir dizi müşteriye hizmet verebilmek için araç filosu aracılıyla optimum rotaların belirlenmesiyle ilgilenir (Toth and Vigo, 2002a). Araç rotalama probleminde temel amaç; müşteri gereksinimlerini karşılayabilmek için mümkün olan en az sayıda araç ve en kısa yolun bulunmasıdır (Christofides, 1976).

Araç rotalama probleminin kısıtlayıcıları ise (Düzakın ve Demircioğlu, 2009):

1. Araçlarla ilgili kısıtlar (kapasite, zaman, çalışma yasası kısıtları gibi)

2. Müşteriler ile ilgili kısıtlar

3. Diğer kısıtlardır.

Araç rotalama probleminin matematiksel modeli kurulurken, öncelikle modelin parametreleri ve karar değişkenlerini tanımlanmıştır (Fisher and Jaikumar, 1981).

\section{Araç rotalama probleminin parametreler;}

$\mathrm{C}_{\mathrm{ij}}=\mathrm{i}$ ile j düğümü(müşteri) arasındaki uzaklık

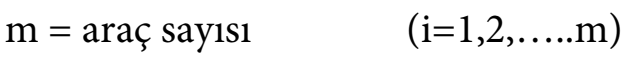

$\mathrm{n}=$ düğüm sayısı $\quad(\mathrm{j}=1,2, \ldots . \mathrm{n})$

$\mathrm{S}=$ düğümler alt kümesi

| S | = S alt kümesindeki düğüm sayısı

$\underline{\text { Araç rotalama problemini karar değișkenleri; }}$ 


$$
\begin{array}{ll}
\left.\mathrm{x}_{\mathrm{i}}\right|_{\mathrm{k}}= & \begin{array}{l}
1, \mathrm{k} \text { aracı } \mathrm{i} \text { düğümünden hemen sonra } \mathrm{j} \text { düğümüne giderse } \\
0, \text { diğer durumda }
\end{array} \\
\mathrm{y}_{\mathrm{i}}= & \begin{array}{l}
1, \mathrm{k} \text { aracı i düğümünü ziyaret ederse } \\
0, \text { diğer durumda }
\end{array}
\end{array}
$$

$\underline{\text { Amaç }}$

Fonksiyonu

Toplam kat edilen mesafenin en küçüklenmesi, denklem 1.1'de gösterilmektedir.

$$
\operatorname{Enkz}=\sum_{i, j} c_{i j} \sum_{k} x_{i j k}
$$

$\underline{\text { Kisitlar }}$

Her müşteri bir araca atanmalıdır; denklem 1.2'te gösterilmektedir.

$$
\sum_{k} y_{i k} \neq \begin{array}{cc}
1, & i= \\
2, \ldots, n & =-
\end{array}
$$

Bir araçla bir düğüme en fazla bir kez uğranabilmelidir (i dügüumüne $\mathrm{k}$ aracı ile gelindiyse ve i dügümünden de j düğümüne geçilecekse, bu geçiş yine $\mathrm{k}$ aracı ile olmalıdır); denklem 1.3'te gösterilmektedir.

$$
\begin{gathered}
\sum_{k} x_{i j k}=y_{i k} \\
\forall(i, k) \quad k=1, \ldots, n \quad m
\end{gathered}
$$

Alt rota oluşması engellenmelidir; denklem 1.4'te gösterilmektedir.

$$
\begin{array}{ll}
\sum_{i, j \in S} x_{i j k} & \leq|\mathrm{S}|-1 \\
\forall(k) & S \subseteq\{2, \ldots, n\} \quad k=1, \ldots, m
\end{array}
$$

Karar değişkenleri 0-1 tamsayılı değişken olmalıdır; denklem 1.5’te gösterilmektedir.

$$
\begin{array}{lll}
\mathrm{y}_{\mathrm{ik}} \in\{1,0\} & i=1, \ldots, n & k=1, \ldots, m \\
\mathrm{x}_{\mathrm{ijk}} \in\{1,0\} & i, j=1, \ldots, n & k=1, \ldots, m
\end{array}
$$

$\mathrm{Bu}$ tanımlamalar altında araç rotalama probleminin genel matematiksel modeli aşağıdaki gibidir;

Amaç fonksiyonu:

$$
E n k z=\sum_{i, j} c_{i j} \sum_{k} x_{i j k}
$$

Kisitlayıcilar:

$$
\sum_{k} y_{i k}=\left[\begin{array}{cc}
1, & i \\
k & i
\end{array}\right.
$$

$$
\forall(i, k) \quad i=1, \ldots, n \quad k
$$




$$
\begin{array}{clc}
\sum_{i, j \in S} x_{i j k} \leq|\mathrm{S}|-1 \quad \forall(k) & \multicolumn{1}{c}{\sum_{k} x_{i j k}=y_{i k}} \\
\mathrm{y}_{\mathrm{ik}} \in\{1,0\} & i=1, \ldots, n & k 2, \ldots, n\} \\
\mathrm{x}_{\mathrm{ijk}} \in\{1,0\} & i, j=1, \ldots, n & k=1, \ldots, m
\end{array}
$$

\section{Araç Rotalama Problemi İçin Çözüm Teknikleri}

Araç rotalama problemini çözmek için araştırmacılar tarafından pek çok teknik geliştirilmiştir. Bu çözüm teknikleri kesin çözüm teknikleri ve sezgisel teknikler olarak iki sınıfa ayrılır. Kesin çözüm teknikleri ile optimal çözüm garanti edilebilirken sezgisel teknikler ile optimuma yakın çözümler çok daha kısa sürede bulunabilmektedir (Keskintürk vd., 2015). Araç rotalama problemi için kullanılan başlıca çözüm teknikleri Şekil 1.'de gösterilmektedir.

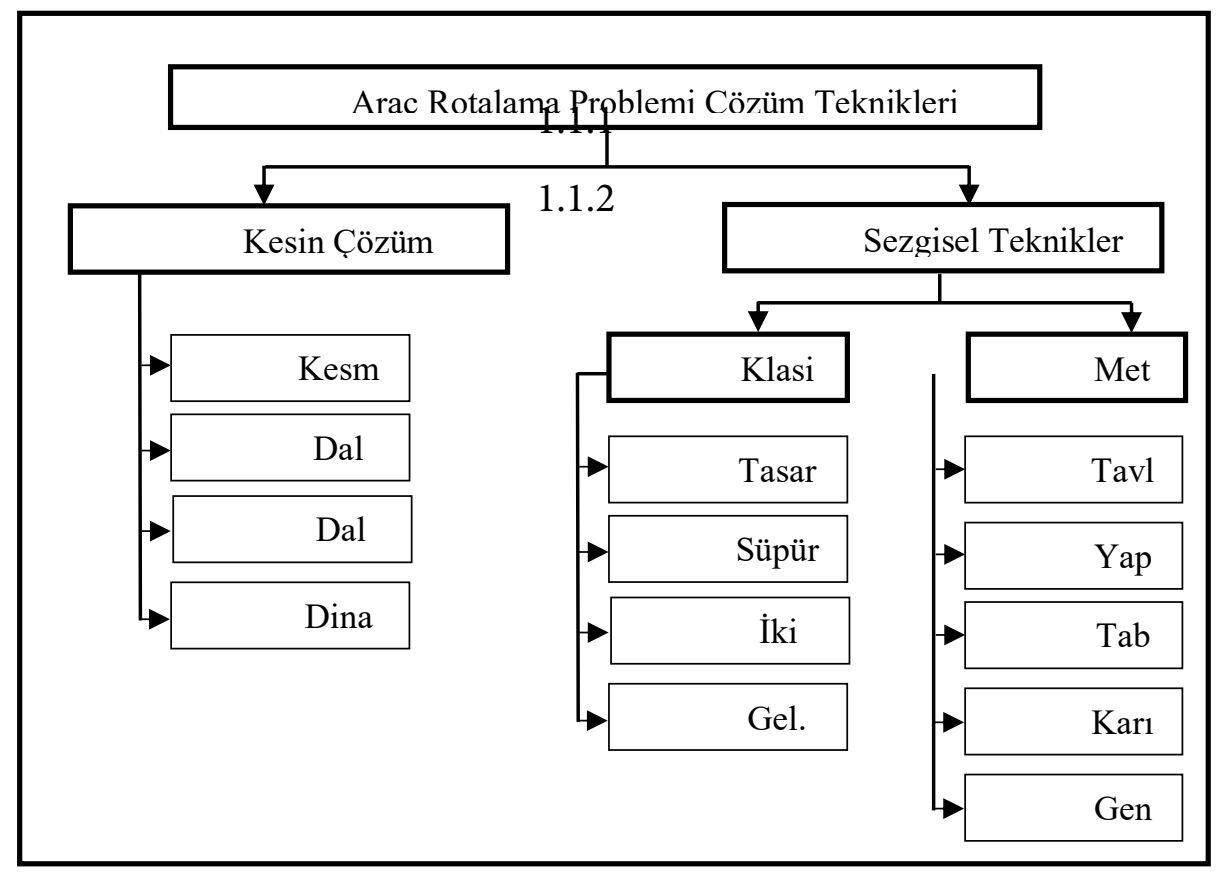

\section{Şekil 1. Araç rotalama problemi çözüm teknikleri (Demircioğlu, 2009 - Düzenleme yapılarak alınmıştır.)}

Bu tekniklerden Genetik Algoritma, son yıllarda da problemlerdeki karmaşıklığı azaltma ve kısa sürede iyi çözümler elde etme özelliği dolayısıyla etkin bir optimizasyon aracı haline gelmiştir (Gupta ve Imtanavanich, 2010).

\section{Araç Rotalama Problemi için Literatür Taraması}

Araç rotalama problemi, ilk olarak Dantzig ve Ramser (1959) tarafından genelleştirilmiş gezgin satıcı problemi olarak ifade edilmiştir. Günlük yaşam problemi için modellenerek özgün bir algoritmaya dayalı çözüm yaklaşımı elde edilmiştir. 1964'te Clarke ve Wright, etkili bir sezgisel algoritmayla farklı araç kapasiteleri ve müşteri talepleri için çözüm yaklaşımını geliştirmişlerdir. Literatürde bu çalışmaları, farklı türdeki araç rotalama problemi modelleri için kesin ya da 
yaklaşık çözüm sunan başka algoritmalar takip etmiştir. Detaylı literatür çalışması, Eksioğlu vd. (2009) tarafından sistematik bir şekilde yapılmıştır (Eksioğlu vd. 2009).

Araç rotalama probleminin pratik uygulamalarında, rotalama sırasında birçok ek gereksinim ve operasyonel kısıtlamalar getirilmiştir. Bahsedilen ek gereksinim ve kısıtlamalar şu şekilde sıralandığında:

- Her güzergâhtaki yük araçların verilen kapasitesini aşmamalı,

- Her güzergahın toplam uzunluğu belirtilen sinırın üzerinde olmamalı,

- Müşterilerin hizmetleri belirli zaman pencerelerinde gerçekleşmeli,

- Araç filosu farklı tip araçlardan oluşabilir,

- Müşteriler arasında öncelik ilişkileri olabilir,

- Müşteri talepleri önceden tam olarak bilinemeyebilir,

- Bir müşterinin talebi farklı araçlar arasında bölünebilir,

- Talepler veya seyahat süreleri gibi bazı problem özellikleri dinamik olarak değişebilir (Toth ve Vigo, 2002a).

Araç rotalama probleminin günlük yaşam uygulamalarında karşılaşılan kısıtlar üç ana grupta toplanabilmektedir (Düzakın ve Demircioğlu, 2009):

1. Araçlarla ilgili kısıtlar

- Araç kapasite kısıtı (ağırlık veya hacim olarak)

- Toplam zaman kisitı

- Sürücünün çalışma saatleri için yasal sınırlamalar

2. Müşteriler ile ilgili kısıtlar

- Her bir müşterinin bir tür ürün talep etmesi veya belirli çeşitte ürün dağıtılması; Lojistik firmaları buna örnek verilebilir.

- Dağıtımın yapılabilmesi için belirli zaman aralıklarının bulunması

3. Diğer kısıtlar

- Aynı araç ile aynı günde, aracın depoya dönerek tekrar yola çıkmasıyla, birden fazla tur yapilması

- Bir turun bir günden uzun olması

- Birden fazla depo olmasi

Araç rotalama probleminde rota oluşturulurken, şu hususlara dikkat edilmelidir (Çeyrekoğlu, 2017):

- Farklı konumlarda bulunan tüm müşterilerin talepleri karşılanmalıdır.

- Her müşteriye talebinin karşılanması için sadece bir araç bir defa uğramalıdır.

- Rotaya depodan başlayan bir araç mutlaka depoya geri dönmelidir.

- Uğranacak müşterilerin talep toplamları araç kapasitesini geçmemelidir.

- Her bir rota için sadece bir araç planlanmalıdır.

- Araç rotalamada temel amaç, her bir aracın kat edeceği mesafenin minimize edilmesi olmalidir.

Şekil 2.'de örnek bir araç rotalama problemi modeli gösterilmiştir. 1'den 9'a kadar numaralanmış düğümler sipariş noktalarını, 0 ise ana depoyu ifade etmektedir. 


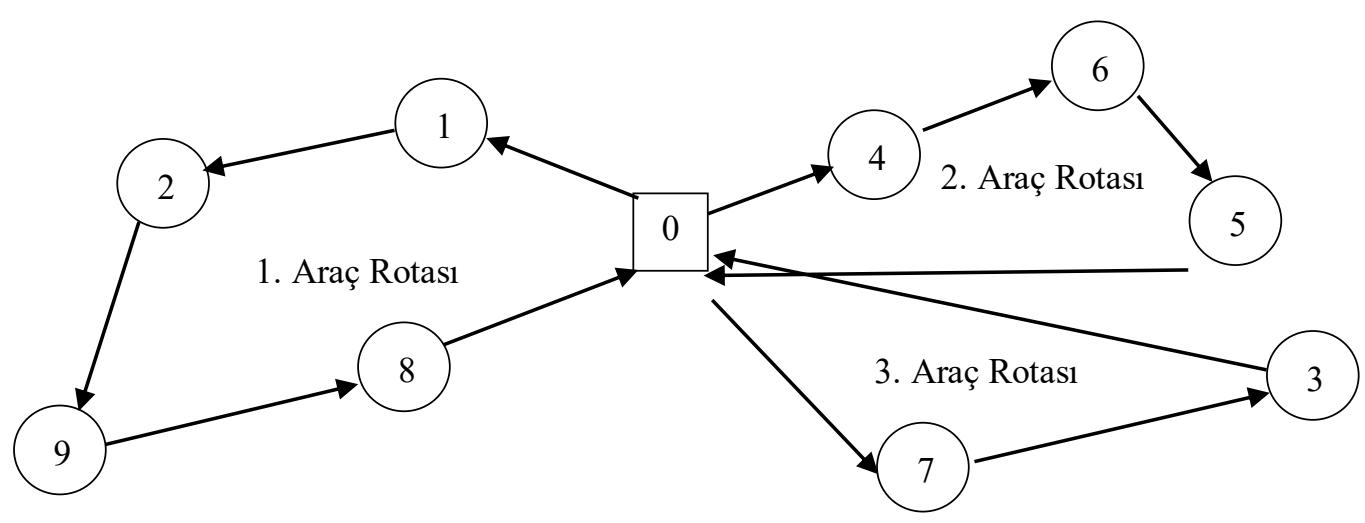

Şekil 2. Araç rotalama problemi örnek gösterimi (Şen, Cömert Ercan ve Yazgan, 2015)

Araç rotalama problemi, gezgin satıcı probleminin birden fazla araç ve eklenmiş kısıtlar ile geliştirilmiş halidir. Araç rotalama probleminin çözümü, aynı sayıda müşteri veya şehre sahip gezgin satıcı problemine kıyasla daha zordur (Düzakın ve Demircioğlu, 2009).

\section{Genetik Algoritma}

Genetik algoritmanın esası doğal seçilim ve genetik kurallarına dayanmaktadır. Bu kurallar, iyi nesillerin kendi yaşamlarını korurken, kötü nesillerin yok olması ilkesine dayanmaktadırlar. Genetik algoritma bu iki kuralı bir arada kullanarak en iyiyi aramayı hedefleyen bir eniyileme tekniğidir (Şen, 2004).

Genetik algoritma genel anlamda, dizilerden oluşan bir popülasyona çoğalma, çaprazlama ve mutasyon operatörlerinin uygulanmasını içermektedir. Bu operatörlerin uygulanmasından sonra yeni bir popülasyon oluşur. Yeni popülasyon eski popülasyon ile yer değiştirir. Her dizinin bir uygunluk değeri vardır. Diziler uygunluk değerine göre seçilirler. Genetik algoritma, optimize edilecek parametreleri kodlar ve bu kodlar üzerinde işlem yaparak parametre kodlama esasına göre çalışır. (Kırda, 2013). Goldberg 'in tanımına göre, genetik algoritma rastlantısal arama tekniğini kullanarak çözüm bulmaya çalışan, parametre kodlama esasına dayanan sezgisel bir arama tekniğidir (Elmas, 2016).

Genetik algoritma problemlere tek bir çözüm üretmek yerine, farklı çözümlerden oluşan bir çözüm kümesi üretir. Genetik algoritmada çözümün uygunluğu onun seçilme şansını arttırır ancak seçilmesini garanti etmez. Seçim işlemi de başlangıç popülasyonunun oluşturulması gibi rastgeledir, ancak bu rastgele işlemde çözüm adaylarının seçilme olasılıklarını çözümlerin uygunluk değerleri belirler (Özkan, 2008). 
Genetik algoritmada olası çözümlerin tümü hemen yaratılmaz. Optimum ya da optimuma yakın çözüme, olası çözümlerin bir bölümü üzerinden gidilir. Genetik algoritma deterministtik kuralları değil, olasılık üzerine kurulu kuralları kullanan teknikdir (Özkan, 2008).

Genetik algoritmanın en uygun olduğu problemler, klasik tekniklerle çözümü mümkün olmayan ya da çözüm süresi problemin büyüklüğüne göre üstel olarak artan durumlarda kullanılmaktadır.

Genetik algoritmanın etkin kullanıldığı alanlar;

- Optimizasyon,

- Otomatik programlama ve bilgi sistemleri,

- Mekanik öğrenme,

- Ekonomik ve sosyal sistem modelleri,

- İşletmelerdeki uygulama alanları görülmektedir (Emel ve Taşkın, 2002).

İşletmelerdeki uygulama alanları: Genetik algoritma işletmelerde finans, pazarlama, üretim, montaj hattı dengeleme problemi, çizelgeleme problemi, tesis yerleşim problemi, atama problemi, hücresel üretim problemi, sistem güvenilirliği problemi, taşıma problemi, gezgin satıcı problemi, araç rotalama problemi, minimum yayılan ağaç problemi gibi birçok farklı problemde kullanılabilmektedir. Bahsedilen problem türlerinin çözümünde başka arama teknikleri de kullanılabilmektedir. Fakat genetik algoritma, genel çözümleri belirleyebilmesi ve alternatiflerin hızlı bir şekilde değerlendirmesi gibi geleneksel tekniklere göre sağladığı üstünlükler sebebiyle daha etkin çözüm tekniği olarak kabul görmektedir. Anlatıldığı gibi genetik algoritma pek çok alanda sıklıkla kullanılmaktadır.

\section{Genetik Algoritmanın Temel Kavramları}

Genetik algoritmanın amacı evrimsel süreci taklit ederek problemlere çözüm üretebilmek olduğu için genetik algoritmadaki birçok kavram genetik bilimindeki karşılıklarıyla benzerlik göstermektedir.

\section{Gen}

Genler, genetik algoritmada çözümün bir özelliğini temsil etmektedirler. Genetik algoritmanın kullanıldı̆̆ı programlama yapısında, gen yapıları programcının tanımlamasına bağlıdır. $\mathrm{Bu}$ nedenle yazılan programa göre gen içeriği çok önemlidir (Elmas, 2007).

\section{Kromozom (Birey)}

Genlerin bir araya gelmesiyle kromozomlar oluşur. Kromozomların bir araya gelmesiyle de popülasyon oluşur. Genetik algoritmada ise her kromozom problem için olası çözümleri temsil eder ve problemin çözümünde en önemli birim olduğu için bilgisayar ortamında iyi ifade edilmesi gerekmektedir.

\section{Popülasyon}

Genetik algoritmada popülasyon, olası çözümlerden oluşan topluluğu temsil etmektedir. Popülasyondaki kromozom sayısı problemin yapısına göre programcı tarafından belirlenir ve nesiller boyunca sabit tutulur. 


\section{Uygunluk Fonksiyonu ve Değeri}

Genetik algoritmada, popülasyon içindeki iyi özelliklere sahip kromozomların bir sonraki nesile aktarılması istenir. Bunun için de problemin amacıyla orantılı olarak oluşturulan uygunluk fonksiyonu kullanılarak bir değerlendirme yapılır.

Uygunluk değeri, çözümün kalitesini belirler ve uygunluk fonksiyonu kullanılarak hesaplanır. Fonksiyonun sonucu olarak ortaya çıkan değer, ilgili kromozomun uygunluk değerini temsil etmektedir. Yüksek değerlere sahip kromozomların bir sonraki nesile aktarılma olasılığ daha fazladır. Yani, iyi olanların korunarak daha iyiye götürebilecek olmasından dolayı, algoritmanın gücünü oluşturan en önemli faktörlerden biri olmaktadır (Yücel, 2016).

\section{Genetik Operatörler}

Genetik algoritmanın en basit formu üç tip genetik operatör içerir: seçim, çaprazlama ve mutasyon

\section{Sonlandırma Kriteri}

Programcı tarafindan belirlenen sonlandırma kriteri, yineleme sayısı (iterasyon sayısı) olabileceği gibi probleme özgü başarı değerleri ya da arama süreside olabilmektedir.

\section{Genetik Algoritmanın Aşamaları}

Genetik algoritma genel olarak aşağıdaki çözüm aşamalarını gerçekleştirir:

1. n adet kromozomdan oluşan rastgele bir popülasyon oluşturulur.

2. Popülasyondaki her kromozomun uygunluk değeri hesaplanır.

3. İlk popülasyon büyüklüğüne ( $n$ adet birey) eşit olan yeni popülasyon oluşturuluncaya kadar aşağıdaki adımlar tekrar edilir.

a) Mevcut popülasyondan seçim teknikleri yardımıyla çaprazlama uygulanacak kromozomlar seçilir.

b) Belirlenmiş olan çaprazlama oranı ile çaprazlama işlemi gerçekleştirilip seçilen kromozomların yerine yeni bireyler oluşturulur.

c) Mutasyon oranı ile yeni oluşturulan bireylere mutasyon uygulanır. Mutasyon uygulanmış olan yeni kromozomlar yeni popülasyonda yer alır.

4. Yeni popülasyon mevcut popülasyon ile yer değiştirilir.

5. 2.aşamaya geri dönülür.

Genetik algoritma süreci için bilgisayar programlarından yararlanılmaktadır. Basit genetik algoritma genel yapısının bilgisayar programında kodlanmasına yönelik yapay kodu Şekil 3.'de verilmiştir. 


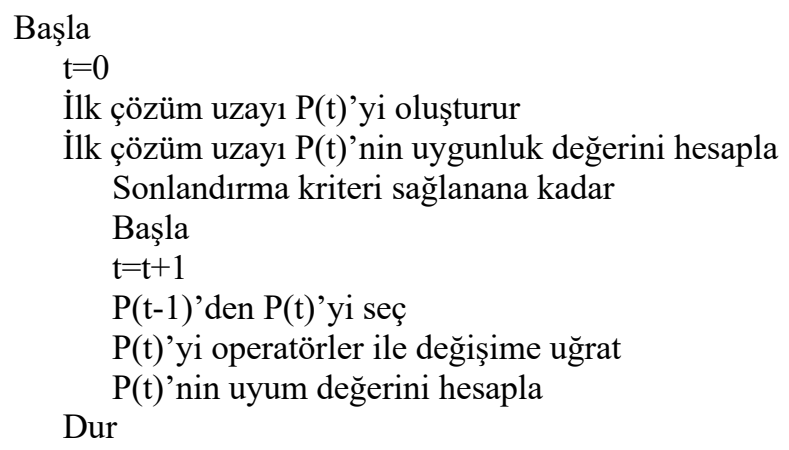

Şekil 3. Genetik algoritmanın genel yapısı (Dasgupta and Michalewicz, 1997)

\section{Genetik Algoritmanın Adımları}

\section{Adım 1. Kromozomların Kodlaması}

Kodlama ile probleme özgü bilgilerin genetik algoritmanın kullanabileceği bir şekle dönüştürülmesi sağlanır. Kodlama, problemin yapısına göre değişiklik göstermektedir. Kromozom kodlamasında İkili kodlama, değer kodlama ve permutasyon kodlama kullanılmaktadır. (Rothlauf, 2006).

Íkili (Binary) kodlama: İlk kez Holland (1975) tarafından önerilen ikili kodlama tekniği, genetik algoritma uygulamalarında en eski ve en yaygın olarak kullanılan gösterimlerden biridir. Çözüm uzayındaki değerlerin ikili sayma sistemine geçirilmesiyle gerçekleştirilir (Yücel, 2016). İkili kodlamada, her kromozom 0 veya 1 karakter dizilerinden oluşmaktadır. Tüm değerlerin temsil edilebileceği şekilde, sabit bir dizi uzunluğu belirlenmelidir. İkili kodlama ile gerçekleştirilen örnek bir kromozom gösterimi Şekil 4.'te verilmiştir (Duman, 2007).

\begin{tabular}{|l|l|}
\hline Kromozom A & 10110010110010101110 \\
\hline Kromozom B & 1111110000011000001 \\
\hline
\end{tabular}

\section{Şekil 4. İkili kodlama gösterimi}

Değer kodlama: Problemin gerçek değerlerinin doğrudan kullanıldı̆̆ 1 kodlama şeklidir. Kodlanan karakterler tamsayılar, ondalıklı sayılar, harfler ya da ilgili problem için anlamlı sözcüklerden oluşabilir. Bu tip problemler için ikili kodlama çok zordur ve hesaplama karmaşıklı̆̆ının artmasına neden olmaktadır. Şekil 5.'te değer kodlamanın alabileceği değerleri gösteren örnek kromozom yapıları verilmiştir (Sivanandam and Deepa, 2008).

\begin{tabular}{|l|l|}
\hline Kromozom A & ADBHNJMKLERTY \\
\hline Kromozom B & $(1,234),(5,678),(4,678)$ \\
\hline Kromozom C & (ön), (sağ), (ön), (arka) \\
\hline
\end{tabular}

Şekil 5. Değer kodlama gösterimleri

Permutasyon kodlama: Genellikle siralama problemlerinde permutasyon kodlama kullanılır. Bu kodlamada her kromozom dizideki bir sırayı temsil eden sayılardan oluşur. Permutasyon 
kodlama, genellikle iş çizelgeleme, gezgin satıcı problemi, araç rotalama problemi gibi sıralamanın önemli olduğu problemlerin çözümde kullanılır. Şekil 6.'da permutasyon kodlama örneği verilmiştir (Günay, 2013).

\begin{tabular}{|l|l|}
\hline Kromozom A & 135792468 \\
\hline Kromozom B & 123498765 \\
\hline
\end{tabular}

Şekil 6. Permutasyon kodlama gösterimleri

\section{Adım 2. Başlangıç popülasyonunun oluşturulması}

Popülasyonu oluşturan kromozomlar, problemin çözüm uzayındaki farklı noktaları temsil ettiği için çözüm uzayının farklı noktaları eş zamanlı olarak taranmaktadır.

Başlangıç popülasyonu çoğunlukla rastgele olarak belirlenir. Popülasyondaki bireylerin başka sezgisel tekniklerle belirlendiği yaklaşımlarda mevcuttur (Sivanandam and Deepa, 2008). Başlangıç popülasyonunun sezgisel teknikler kullanılarak oluşturulması optimum çözüme ulaşmayı hızlandırabilecekken, bazı durumlarda çeşitliliği azaltarak yerel optimuma takılmaya neden olabilmektedir (Gomez and Hougen, 2007).

Popülasyondaki kromozom sayısı programcı tarafından belirlenir ve sonraki nesiller boyunca sabit tutulur. Popülasyon büyüklüğü genetik algoritmanın performansı ile doğru orantılıdır. Popülasyon boyutunun büyük olması, çözüm uzayının daha geniş bir bölümünde arama yapılmasını sağlarken, çözüme ulaşma süresini uzatacaktır. Popülasyon büyüklügünün küçük olması ise algoritmanın çalışma hızını arttırırken, çözüm uzayının görece daha az bir kısmını tarayacağı için en iyi çözüme ulaşılma olasılığını azaltacaktır.

\section{Adım 3. Uygunluk fonksiyonunun belirlenmesi ve uygunluk değerinin hesaplanması}

Uygunluk fonksiyonu genetik algoritmanın sağlıklı çalışması ve doğru sonuçlar vermesini etkileyecektir. Genellikle uygunluk fonksiyonu problemin amaç fonksiyonu ya da onun bir dönüşümüdür (Acar,2014).

\section{Adım 4. Seçim operatörü}

Seçim işleminde popülasyondaki bütün bireylerin seçilme olasıllğı vardır. Seçim operatörü, popülasyonun boyutuyla ilişkilidir. Topluluk boyutu küçük bir popülasyonla çalışılması durumunda topluluk çeşitlendirilmesinin olası iyi alternatiflerin oluşması için yetersiz kalması sorununu yaratabilir. Bu nedenle seçimde, popülasyondaki kromozomların çeşitlendirilmesini daraltan bir tekniğin uygulanması iyi sonuç vermeyebilir (Er, Çetin ve İpekçi Çetin, 2005).

Seçim sırasında dengenin gözetilmesi gerekmektedir. Çok güçlü bir seçim, o seviyede iyi uygunluk değerine sahip kromozomların popülasyonu kaplamasını ve çözüme ulaşmak için gereken çeşitliliğin azalmasını beraberinde getirir. Çok zayıf bir seçim ise aşırı yavaş bir evrime sebep olur (Cevre, 2008). Hangi kromozomların bir sonraki nesile aktarılacağını belirlemek için farklı seçim teknikleri geliştirilmiştir. Seçim tekniklerinden rulet tekerleği tekniği, turnuva seçim tekniği ve elit seçim tekniği en çok kullanılanlardır. 


\section{Adım 5. Çaprazlama operatörü}

Çaprazlama, Genetik algoritmanın performansını etkileyen önemli işlemlerden biridir. Çaprazlama üç adımda gerçekleştirilen bir operatördür (Sivanandam and Deepa, 2008):

i. Seçim operatörü rastgele eşleşme için iki ayrı diziden bir çift seçer.

ii. Çaprazlama konumu dizi uzunluğu boyunca rastgele seçilir.

iii. Son olarak, konum değerleri çaprazlama takiben iki dizi arasında değiştirilir.

Seçim işlemi ile belirlenen kromozomların yer aldığı bir çiftleşme havuzu oluşturulduktan sonra gerçekleştirilen çaprazlama işlemlerinin genellikle tümünde, iki ebeveyn birey, bir çiftleşme havuzundan alınarak karşılıklı genlerini değiştirirler. Bu sayede çaprazlama operatörünün çalıştırılmasıyla popülasyonda yer almayan yeni bireyler oluşturularak çeşitlilik sağlanır (Yücel, 2016).

Aynı kromozom çiftlerinden farklı yavru kromozom meydana gelebilmesinden dolayı çaprazlama operatörü genellikle stokastiktir (Dreo vd., 2006).

\section{Adım 6. Mutasyon operatörü}

Mutasyon operatörü, popülasyonda genetik çeşitliliği sağlamak ve korumak amacıyla kullanılır (Çolak, 2010). Mutasyon, başka türlü bulunamayacak olası çözümlere ulaşmanın rasgele bir yoludur (Karaova, Smarkov and Penev, 2005).

Mutasyon işlemi, önceki işlemlerde kaybedilen yararlı genlerin kurtarılması için tasarlanmıştır. Mutasyon işleminde, mutasyon olasılığına bağlı olarak kromozomdaki değer değiştirilir (Chen and Chen, 1997). Mutasyon işlemi, tüm kromozomlara uygulanmayıp sadece üretilen çocukların belli bir yüzdesine uygulanır. Bu yüzdeye mutasyon olasılığı veya mutasyon oranı denir. Mutasyon olasılığı, problemin başında belirlenen ve genellikle (0,01 gibi) çok düşük bir oranla gerçekleştirilir. Eğer mutasyon olasılı̆̆ 1 çok büyük olursa, bu kromozomların gereğinden fazla değişikliğe uğraması anlamına gelir ve çözümün optimuma ulaşması zorlaşabilir (Kırda, 2013).

\section{Adım 7. Sonlandırma kriteri ve algoritmanın sona ermesi}

Genetik algoritmanın bir yerde sona ermesi ve sonucunun elde edilmesi için karar verici tarafından belirlenen bir kriterin sağlanmış olması gereklidir (Koza, 1998).

Genetik algoritma sürecinde en yaygın olarak kullanılan sonlandırma kriteri, belirli bir yineleme sayısına ulaşılmasıdır. Yücel, 2016). Genetik algoritmanın temel işleyişine ait akış şeması ise Şekil 7.'de verilmiştir. Akış şemasında görüldüğü gibi genetik algoritmanın ilk adımı uygun kodlamanın yapılmasıdır. 


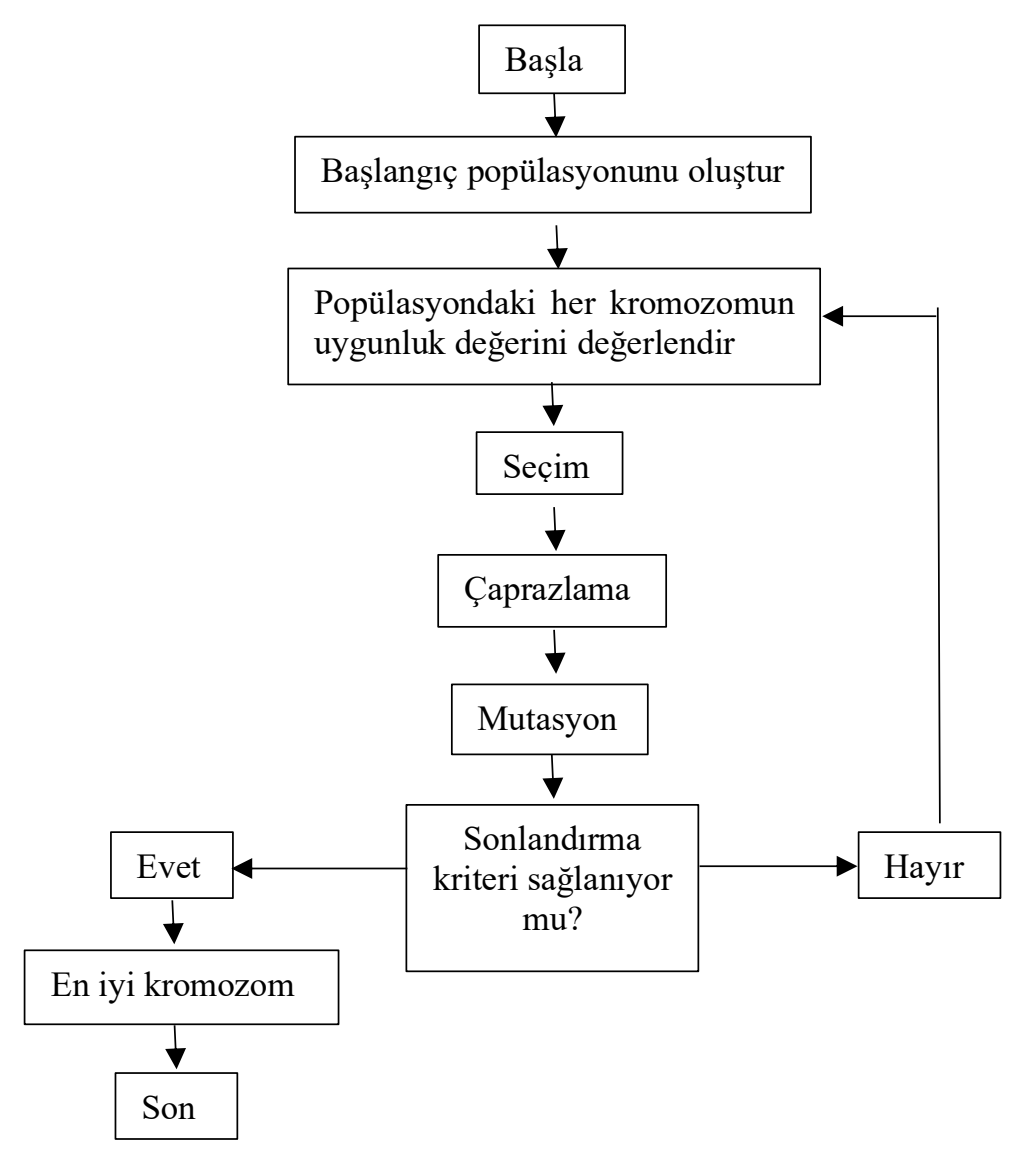

Şekil 7. Genetik algoritmanın akışs şeması

\section{Genetik Algoritmanın Özellikleri}

Genetik algoritmanın kullanılmasının başlıca avantaj ve dezavantajları şu şekilde belirtilmektedir (Haupt and Haupt, 2004):

\section{Avantajları;}

- Sürekli ya da kesikli değişkenlerden oluşan problemlerde optimum çözümler verebilmektedir.

- Ek bilgilere ihtiyaç duymadan çalışabilmektedir.

- Çok sayıda değişkenle çalışabilmektedir.

- Geniş çözüm uzayında eş zamanlı tarama yapabilmektedir.

- Değişkenler üzerinde kodlama yapılmasına izin vermektedir.

\section{Dezavantajları;}

Genetik algoritma, Sivanandam and Deepa, 2008):

- Uygunluk fonksiyonunun belirlenmesi zorluk çıarabilmektedir.

- Erken yakınsama oluşabilir.

- Popülasyon büyüklügü, mutasyon olasıllı̆̆ı, çaprazlama olasılığı, seçim tekniği gibi çeşitli parametrelerin seçilmesi problemi vardır.

- Özel bilgiler probleme kolayca dahil edilemez.

- Yerel optimumun belirlenmesinde iyi değildir. 
- Kesin bir sonlandırma kriteri bulunmamaktadır.

- Düzgün tek modlu fonksiyonlar için etkili değildir.

- Bir yerel arama tekniği ile birlikte kullanılması gerekir.

- Tam olarak global optimumu bulmak zordur.

- Çok sayıda uygunluk fonksiyonu değerlendirmesi gerektirir.

- Yapılandırma basit değildir.

\section{Genetik Algortima Kullanılarak Ekmek Üretim İşletmesi İçin Araç Rotalama Probleminin Çözümü}

Araç rotalama probleminin, genetik algoritma tekniği ile çözümü bir uygulama ile gösterilmeye çalışılacaktır. Uygulama, Eskişehir'de bulunan ve günlük ekmek üretip dağıtan, ekmek fabrikasında yapılmıştır. Uygulama amacı; müşteri taleplerinin tümü karşılanırken, en kısa rotayı oluşturabilmek için işletmeye ait hangi aracın hangi siparişleri nasıl bir sırayla taşıması gerektiği belirlenmeye çalışılmasıdır.

Eskişehir Halk Ekmek İşletmesi üretim tesisi 6750 adet / saat beyaz ekmek, 10000 adet / saat roll ekmek üretim kapasitesine sahiptir. Tesiste beyaz ekmek dışında ayrıca kepekli ekmek, tam buğday ekmek ve roll ekmek çeşitleri olmak üzere dört çeşit ekmek üretilmektedir. Ekmek çeşitlerine ait görseller Şekil 8.'de verilmektedir.
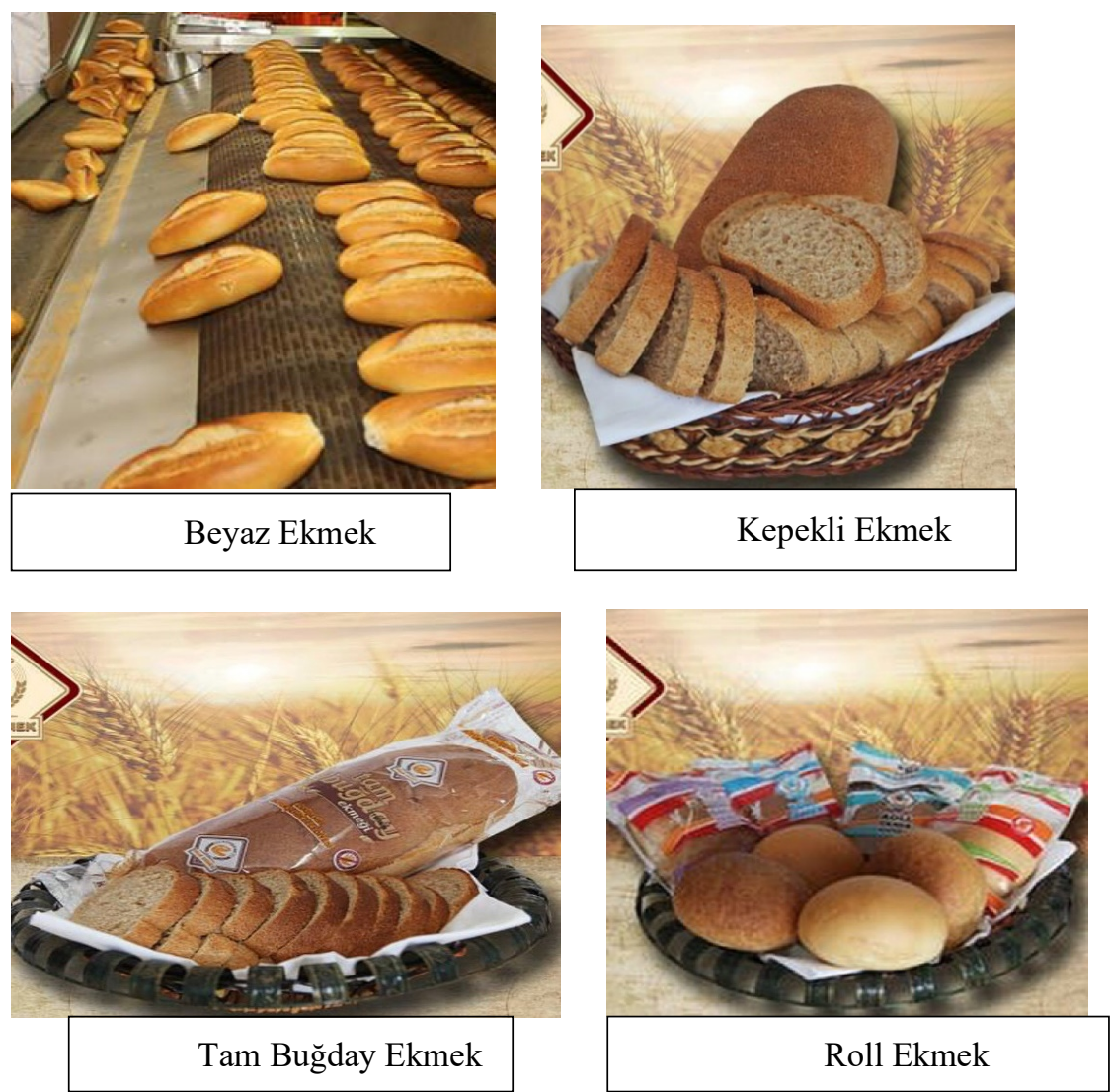

Şekil 8. Eskişehir Halk Ekmek İşletmesi'ne ait ürünler (http://www.eskisehirhalkekmek.com/, 28 Haziran 2019) 
Ekmekler, tek bir üretim tesisinde üretilerek 51 adet satış büfesi aracılığıyla halka ulaştırılmaktadır. Bu çalışma kapsamında, tesisin satış büfelerine ekmek dağıtımı ele alınmaktadır. Üretim tesisinin ve dağıtım noktalarının adresleri bilindiği için Eskişehir Halk Ekmek İşletmesi'nin mevcut üretim tesisi ve satış büfelerinin Google Maps (https://www.google.com/maps) üzerindeki konumları Şekil 9'de görsel olarak gösterilmektedir. Bu şekilde ilgili 51 noktanın yerlerinin toplu olarak görülmesi sağlanmıştır.

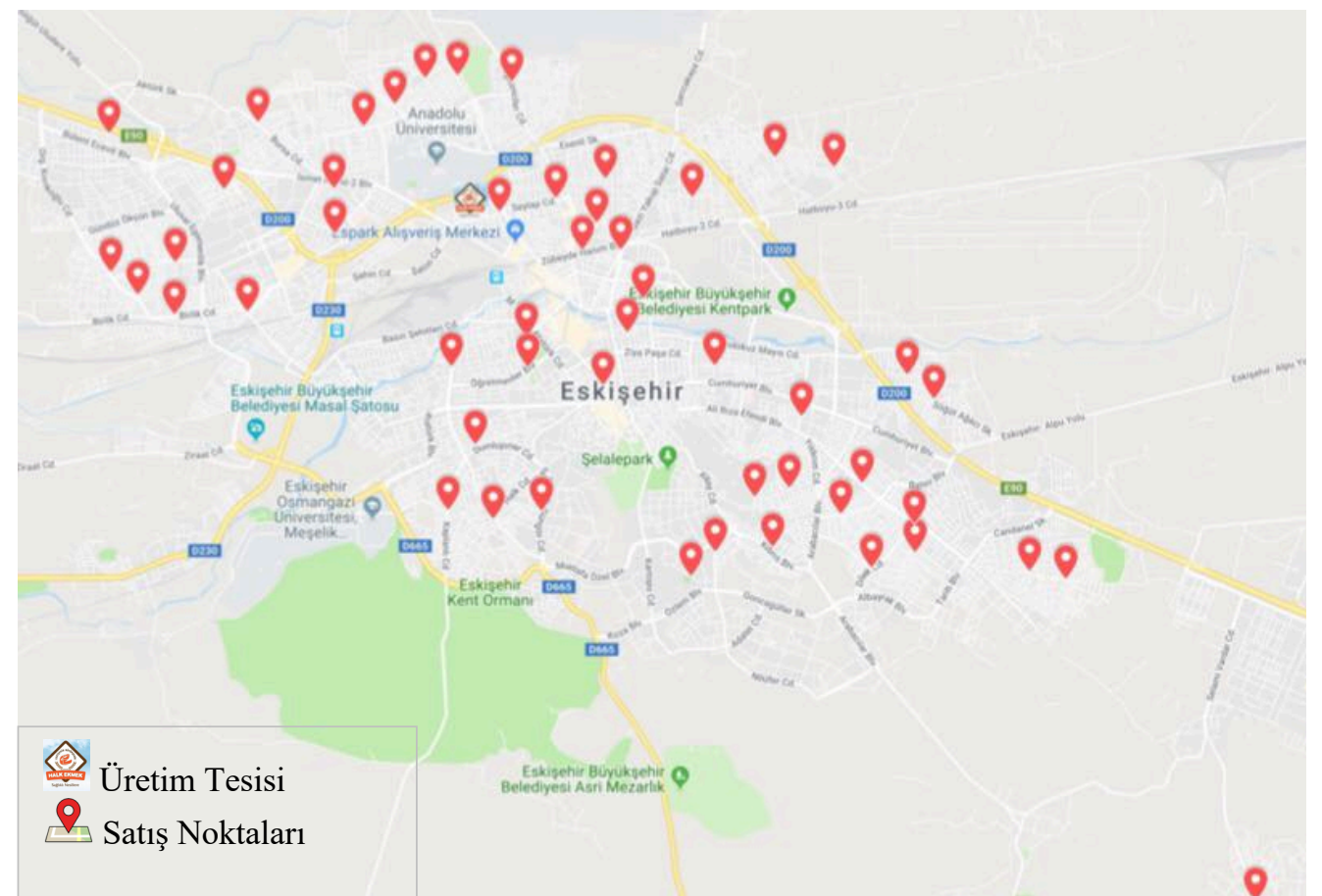

Şekil 9. Eskişehir Halk Ekmek İşletmesi üretim tesisi ve satış noktalarının konumları

(https://drive.google.com/open?id=1QSWTXqzZLq-1cQNo3z13D58Pdml7twya\&usp=sharing, 28 Haziran 2019)

Eskişehir Halk Ekmek İşletmesi 3 araca sahiptir. Araçların her biri bir seferde 150 kasa ekmek taşıma kapasitesine sahiptir. Her bir kasada 20 adet beyaz ekmek/kepekli ekmek/tam buğday türünde ekmek ayrıca 80 adet roll ekmek yer alabilmektedir.

Siparişler önceden bellidir ve günlük olarak oluşturulmaktadır. Araçlar üretim tesisinden (depo) dağıtıma çıkmaktadır ve dağıtım sonunda tekrar üretim tesisine dönmektedir.

Birden fazla araç ve belirli bir kapasite kısıtı olduğu için problem araç rotalama problemi kapsamında yer almaktadır. Ele alınan problemde amaç, satış büfelerinin siparişlerinin tümünü karşılayacak olan araç rotalarını belirleyerek toplam en kısa mesafeyi elde etmektir.

$\mathrm{Bu}$ amaçla problemin varsayımları:

- Bir noktaya sadece bir aracın gitme zorunluluğu vardır ve bir noktaya sadece bir kez uğranılmalıdır.

- Her müşteri yalnızca bir araca atanmalıdır.

- Her araç sadece bir rotada kullanılacaktır. 
- Her noktaya en az bir defa uğranılmalıdır.

- Varılan her nokta aynı araçla terkedilmelidir.

- Her araç dağıtım rotasına depoda başlayıp depoda sonlandırmaktadır.

- Her aracın kapasitesi 3000 adet beyaz ekmek, tam buğday ve kepekli ekmek kadardır. Eğer araç kapasitesi, rotasındaki noktaların sipariş miktarını (talebini) karşılayamayacaksa (kapasite aşımı), kapasitesi kadar ürünün dağıtımını rotasındaki belirli noktalara dağıtıp tekrar depoya geri dönmeli ve aracını doldurmalıdır. Rotasındaki tüm noktaların siparişleri karşılanana kadar bu döngüyü devam ettirmelidir.

- Dağıtım noktaları ve üretim tesisi (depo) noktası arasındaki mesafeler belirlidir ve herhangi bir durumdan (yol çalışması, kaza, hava şartları vb.) etkilenmediği varsayılmıştır.

- Herhangi bir zaman süresi ve servis süresi kısıtı bulunmamaktadır.

\section{Uygulama Problemi Verileri}

Uygulamada Eskişehir Halk Ekmek İşletmesi'nin bir güne ait sipariş miktarlarından yararlanılmıştır ve yaklaşık olarak diğer günlerde de aynı miktarlarda sipariş olacağı öngörülmüştür.

Eskişehir Halk Ekmek İşletmesi'ne ait bir günlük sipariş miktarı tablosu Tablo 1.'de verilmektedir. Üretim tesisinin numaralandırılması bir (1) olarak belirlendiği için satış büfelerinin numaralandırılması ikiden (2) başlatılmıştır. 
Tablo 1. Eskişehir Halk Ekmek İşletmesi bir günlük sipariş miktarları

\begin{tabular}{|c|c|c|c|c|c|c|}
\hline \multirow{2}{*}{$\begin{array}{c}\text { Satış } \\
\text { Büfelerinin } \\
\text { Numaraları }\end{array}$} & \multirow{2}{*}{$\begin{array}{c}\text { Satı̧̧ Büfelerinin } \\
\text { İsimleri }\end{array}$} & \multicolumn{4}{|c|}{ Sipariş Miktarları (adet) } & \multirow{2}{*}{$\begin{array}{l}\text { Toplam } \\
\text { Satış } \\
\text { Miktarları } \\
\text { (adet) }\end{array}$} \\
\hline & & $\begin{array}{l}\text { Beyaz } \\
\text { Ekmek }\end{array}$ & $\begin{array}{l}\text { Kepekli } \\
\text { Ekmek }\end{array}$ & $\begin{array}{c}\text { Tam } \\
\text { Buğday } \\
\text { Ekmek }\end{array}$ & $\begin{array}{c}\text { Roll } \\
\text { Ekmek } \\
\text { (Eşitlendi) }\end{array}$ & \\
\hline 2 & 71 Evler-1 & 1000 & 40 & 40 & - & 1080 \\
\hline 3 & 71 Evler-2 & 200 & - & 20 & - & 220 \\
\hline 4 & Bağlar & 160 & 40 & 40 & 30 & 270 \\
\hline 5 & Batıkent & 160 & 40 & 40 & 15 & 255 \\
\hline 6 & Batıkent-2 & 50 & 20 & 30 & 13 & 113 \\
\hline 7 & Büyükdere & 740 & 60 & 100 & 18 & 918 \\
\hline 8 & Çamlıca-1 & 340 & 40 & 60 & 8 & 448 \\
\hline 9 & Çamlıca-2 & 580 & 40 & 40 & 24 & 684 \\
\hline 10 & Çamlıca-3 & 600 & 20 & 40 & 4 & 664 \\
\hline 11 & Çamlıca-4 & 520 & 20 & 40 & 7 & 587 \\
\hline 12 & Çankaya & 160 & - & - & - & 160 \\
\hline 13 & Derman & 500 & 40 & 60 & 8 & 608 \\
\hline 14 & Elmalı & 400 & 20 & 20 & 9 & 449 \\
\hline 15 & Emek-2 & 800 & 40 & 40 & - & 880 \\
\hline 16 & Emek-3 & 400 & - & 20 & 5 & 425 \\
\hline 17 & Emek-4 & 1100 & 40 & 40 & 8 & 1188 \\
\hline 18 & Emeksiz & 460 & 20 & 40 & 10 & 530 \\
\hline 19 & Erenköy-1 & 500 & 20 & 20 & 38 & 578 \\
\hline 20 & Ertaş & 800 & 40 & 60 & 13 & 913 \\
\hline 21 & Esentepe & 400 & 20 & 20 & 3 & 443 \\
\hline 22 & Fevziçakmak-1 & 360 & - & - & - & 360 \\
\hline 23 & Fevziçakmak-2 & 400 & - & 10 & - & 410 \\
\hline 24 & Gökmeydan-2 & 500 & 40 & 110 & 30 & 680 \\
\hline 25 & Göztepe & 200 & 20 & 40 & 13 & 273 \\
\hline 26 & Gültepe & 700 & 20 & 80 & 88 & 888 \\
\hline 27 & Hava Hastanesi & 760 & 120 & 220 & 85 & 1185 \\
\hline 28 & Kırım & 260 & 40 & 40 & 8 & 348 \\
\hline
\end{tabular}


Tablo 1. Eskişehir Halk Ekmek İşletmesi bir günlük sipariş miktarları (Devamı)

\begin{tabular}{|c|c|c|c|c|c|c|}
\hline \multirow{2}{*}{$\begin{array}{c}\text { Satış } \\
\text { Büfelerinin } \\
\text { Numaraları }\end{array}$} & \multirow{2}{*}{$\begin{array}{c}\text { Satış Büfelerinin } \\
\text { İsimleri }\end{array}$} & \multicolumn{4}{|c|}{ Sipariş Miktarları (adet) } & \multirow{2}{*}{$\begin{array}{l}\text { Toplam } \\
\text { Satış } \\
\text { Miktarları } \\
\text { (adet) }\end{array}$} \\
\hline & & $\begin{array}{l}\text { Beyaz } \\
\text { Ekmek }\end{array}$ & $\begin{array}{l}\text { Kepekli } \\
\text { Ekmek }\end{array}$ & $\begin{array}{c}\text { Tam } \\
\text { Buğday } \\
\text { Ekmek }\end{array}$ & $\begin{array}{c}\text { Roll } \\
\text { Ekmek } \\
\text { (Eşitlendi) }\end{array}$ & \\
\hline 29 & Kurtuluş & 400 & 60 & 100 & - & 560 \\
\hline 30 & Odunpazarı & 640 & 80 & 160 & - & 880 \\
\hline 31 & Opera & 280 & 40 & 80 & - & 400 \\
\hline 32 & Ömerağa & 340 & 40 & 60 & - & 440 \\
\hline 33 & Savaş & 280 & 40 & 140 & 30 & 490 \\
\hline 34 & Sihhiye & 260 & 40 & 60 & 18 & 378 \\
\hline 35 & Sultandere-1 & 280 & 20 & 40 & 25 & 365 \\
\hline 36 & Şahintepesi & 360 & 40 & 40 & 13 & 453 \\
\hline 37 & Şarhöyük & 220 & - & - & - & 220 \\
\hline 38 & Şirintepe & 440 & 40 & 60 & 18 & 558 \\
\hline 39 & Takkal1-1 & 800 & 40 & 40 & 122 & 1002 \\
\hline 40 & Takkalı-2 & 400 & 20 & 20 & - & 440 \\
\hline 41 & Tepebaşı & 700 & 80 & 140 & 23 & 943 \\
\hline 42 & Toki-3 & 300 & 20 & 80 & 17 & 417 \\
\hline 43 & Toki-5 & 400 & 20 & 20 & - & 440 \\
\hline 44 & Uluönder & 300 & 20 & 40 & 12 & 372 \\
\hline 45 & Vişnelik & 340 & 40 & 200 & 48 & 628 \\
\hline 46 & Yenidoğan-1 & 600 & 60 & 80 & 38 & 778 \\
\hline 47 & Yenikent & 560 & 60 & 160 & 29 & 809 \\
\hline 48 & Yeşiltepe-1 & 400 & 20 & 20 & 7 & 447 \\
\hline 49 & Yeşiltepe-2 & 400 & - & - & - & 400 \\
\hline 50 & Yimpaş & 280 & 20 & 40 & 12 & 352 \\
\hline 51 & Yunustepe & 700 & 60 & 60 & 8 & 828 \\
\hline 52 & Zincirlikuyu & 480 & 40 & 40 & 7 & 567 \\
\hline
\end{tabular}

Üretim tesisi ve satı̧̧ büfeleri arasındaki mesafeler Google Maps (https://www.google.com/maps) aracılığı ile bulunmuştur. Mesafe değerlerinin belirlenmesi aşamasında koordinat veya kuş uçuşu mesafe değerleri yerine gerçek yol güzergahının km değerlerinin kullanılması sayesinde uygulamanın daha gerçekçi sonuçlar vermesi amaçlanmaktadır. 


\section{Uygulama Probleminin Genetik Algoritma ile Çözümü}

Probleminde genetik algoritmanın kullanılabilmesi için hesaplamayı sağlayacak bir yazılıma gereksinim duyulmaktadır. Hesaplamalar çok uzun süreceği için elle hesaplama yapmak mümkün değildir. Bu sebeple, bilgisayarların hızlı işlem yapma özelliğinden yararlanmak amacıyla bir yazılım geliştirilmiştir.

Problemin genetik algoritma ile çözümünde, Java programlama dili kullanılarak Java web uygulaması şeklinde geliştirilmiştir. Ara yüz teknolojisi olarak AngularJs, JavaScript, HTML, CSS ve Bootstrap teknolojileri kullanılmıştır. Veri tabanı olarak ise MySQL kullanılmıştır. Geliştirilen yazılım, Windows 10 işletim sisteminde çalışan, SSD sabit disk, 8 GB RAM ve 3.20 $\mathrm{GHz} 4$ çekirdekli AMD işlemciye sahip bir bilgisayar üzerinde denenmiştir. Geliştirilen yazılım, daha sonra internet ortamında erişilebilir hale getirilmiştir.

Öncelikli olarak, uygulama verileri program veri tabanına eklenmelidir. Sonrasında genetik algoritmanın çalışma düzenine göre çalıştırılmaktadır. Yazılımın ara yüzü, genetik algoritmanın çalışma prensibini temel alan 6 kısımdan oluşmaktadır ve Şekil 10'da gösterilmektedir. Başlangıç popülasyonunun oluşturulmasından başlayarak hesaplama, seçim, çaprazlama, mutasyon ve son olarak genetik algoritma çözüm sonuçlarının gösterildiği algoritma kısmı şeklinde devam etmektedir.

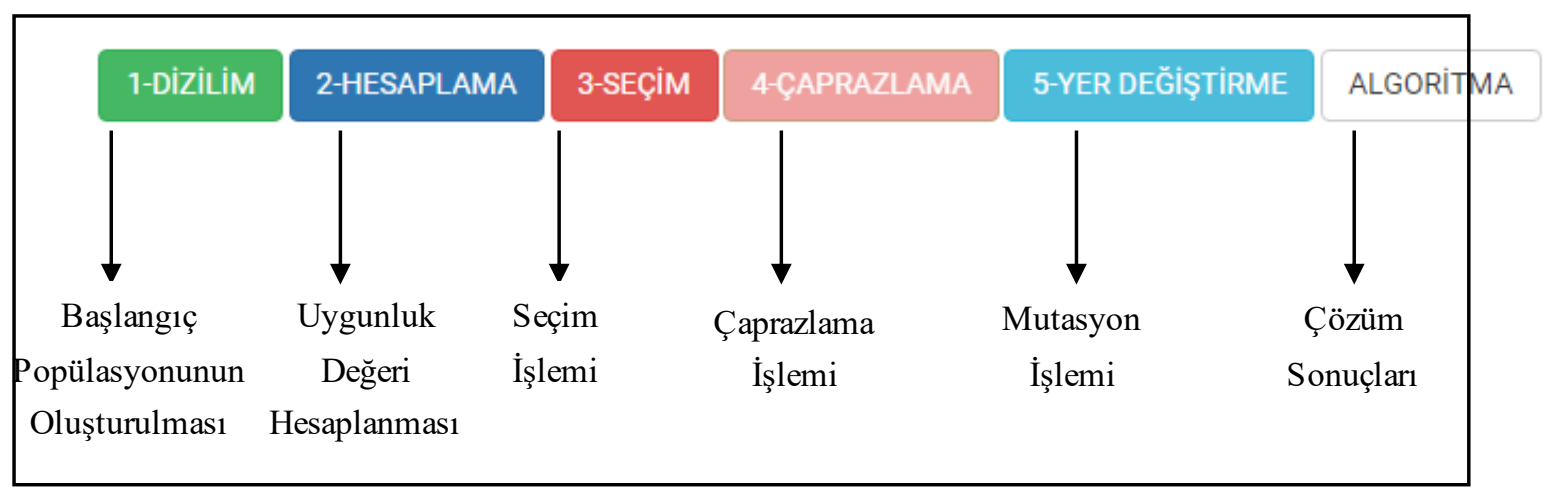

Şekil 10. Yazılımın ara yüzündeki kısımların görseli

\section{Kromozom yapısı ve başlangıç popülasyonu}

Genetik algoritmanın temel kavramları, Eskişehir Halk Ekmek İşletmesi ekmek dağıtım probleminde:

- Gen: Dağıtım rotasındaki üretim tesisi ve 51 satış büfesinden oluşan noktaların her biri,

- Kromozom: Problemin olası çözümünü temsil eden araç rota güzergâhlarının her biri,

- Başlangıç Popülasyonu: Rastgele oluşturulan araç rota güzergâhlarının kümesi şekilde ifade edilmektedir.

Başlangıç popülasyon büyüklüğü parametresi 100 olarak belirlenmiştir ve bu sayı üretilecek çözüm sayısını ifade etmektedir. Kromozom yapısı oluşturulurken üç araç için toplam en kısa mesafeyi bulmayı amaçlayan bir yapı tasarlanmıştır, çözüm sonuçları sonrasında bulunan rota üç araç arasında dengeli bir şekilde dağıtılmaya çalışılacaktır. Problemin kromozom yapısı ve başlangiç popülasyonu örneği Tablo 2'de verilmektedir. 
Tablo 2. Probleme ait kromozom yapısı ve başlangıç popülasyon örneği

1. Dizilim

2. Dizilim

3. Dizilim

\begin{tabular}{|c|c|c|c|c|c|c|c|c|c|c|c|}
\hline 1 & 11 & 24 & 3 & 43 & 23 & 1 & $\cdots$ & 27 & 50 & 20 & 1 \\
\hline 1 & 37 & 44 & 24 & 22 & 40 & 35 & $\cdots$ & 52 & 10 & 18 & 1 \\
\hline 1 & 41 & 14 & 44 & 7 & 1 & 19 & $\cdots$ & 27 & 18 & 48 & 1 \\
\hline
\end{tabular}

1

1
1

100. Dizilim

\begin{tabular}{|l|l|l|l|l|l|l|l|l|l|l|l|}
\hline 1 & 18 & 14 & 15 & 3 & 43 & 32 & $\cdots$ & 4 & 1 & 40 & 1 \\
\hline
\end{tabular}

İkinci bölümde belirtildiği üzere genetik algoritmalarda kromozomlar çözüme ait tüm bilgileri içinde bulundururlar. Tabloda bir (1) ile gösterilen gen üretim tesisini, diğer sayılar ise dağıtım noktalarını ifade etmektedir. Problemin yapısı gereği dağıtım, üretim tesisinden başlayarak üretim tesisinde sonlanması gerektiğinden kromozomun ilk ve son geninde üretim tesisi konumlandırılmıştır. Aynı zamanda, kapasite kısıtına uygun olacak şekilde dağıtım noktalarının arasına üretim tesisini ifade eden bir (1) sayısı tekrar kullanılmakta ve dizilimler bu kurala uygun olacak bir şekilde oluşturulmaktadır.

\section{Uygunluk fonksiyonu}

Kromozomlar oluşturulduktan sonra uygunluk değerinin hesaplanması gerekir. Uygunluk değeri, kromozoma ait sıralamadaki ardışı her iki nokta arasındaki mesafenin toplanması sonucu elde edilmektedir. Problemin amacı en kısa mesafeyi elde etmek olduğu için uygunluk değeri ne kadar küçükse bulunan çözüm o kadar iyidir. Uygunluk fonksiyonuna ait geliştirilen yazılımın ara yüzü Şekil 11'da verilmektedir. 


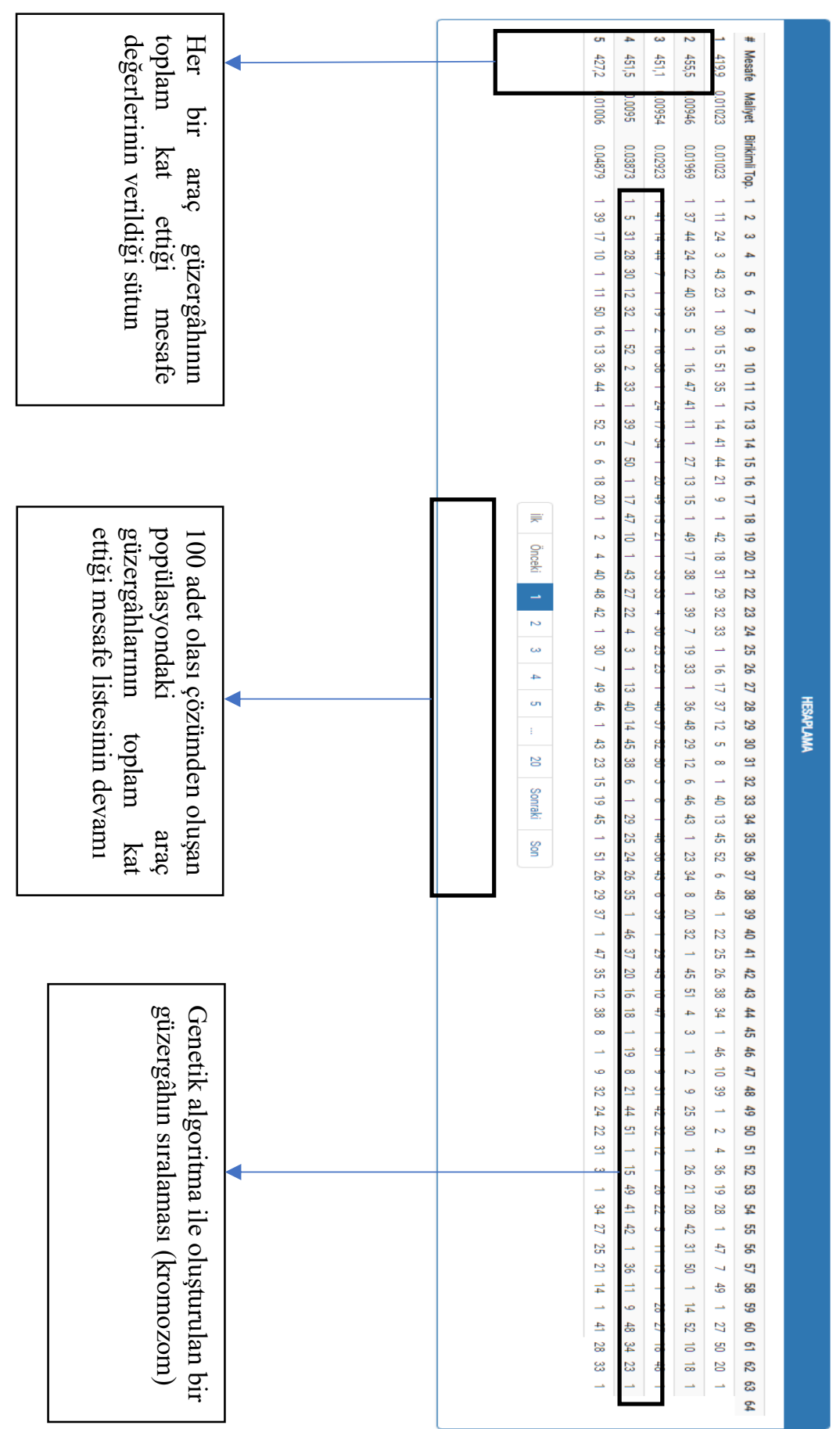

Şekil 11. Uygunluk fonksiyonunun geliştirilen yazılımdaki ara yüz görseli

\section{Genetik operatörler}

Genetik operatörlerin uygulanması aşamasında kromozom yapısına kapasite kısıtlaması nedeniyle eklenen üretim tesisi geni olmadan yani popülasyonun ham haliyle işlem yapılmaktadır. Bunun sebebi, işlemler sırasında oluşabilecek karmaşıklığı engellemektir. Dizilimlerin ham hallerinin geliştirilen yazllımın ara yüzündeki görseli Şekil $12^{\text {‘de }}$ gösterilmektedir. 


\section{Şekil 12. Başlangıç popülasyonunun geliştirilen yazılımdaki ara yüz görseli}

Seçim işlemi: Başlangıç popülasyonunun oluşturulması ve popülasyondaki her bireyin uygunluk değerinin hesaplanmasının ardından sıra seçim aşamasına gelir. Bu çalışmada, seçim işleminde rulet tekerleği seçimi kullanılmaktadır. Seçim işlemiyle popülasyonda en güçlü adayların yani uygunluk değeri daha iyi olan adayların bir sonraki popülasyona aktarılma ihtimali artmaktadır.

Rulet tekerleği seçim tekniğinde; popülasyonda bulunan her güzergâhın (her bireyin) uygunluk değeri öncelikle bire bölünmelidir. Problemin amacı en kısa mesafenin elde edilmesi olduğundan çözüm kümesi içinde en kısa mesafenin en büyük oranı vermesini sağlamak için bu işlem gerçekleştirilmektedir. Sonrasında bu oranların birikimli toplamları hesaplanır. İyi değere sahip bireylerin oranının daha yüksek olması sebebiyle bir sonraki popülasyona 
aktarılma ihtimalinin yüksek olması beklenir. Sonrasında popülasyon büyüklüğü kadar [0-1] arasında rasgele değerler üretilir, bu değer hangi dizilimin birikimli ihtimalinden küçükse o dizilim seçim işlemine tabi tutulur. Rulet tekerleği seçim tekniğinin yazılım ara yüzü üzerindeki görseli Şekil 13`de verilmektedir.

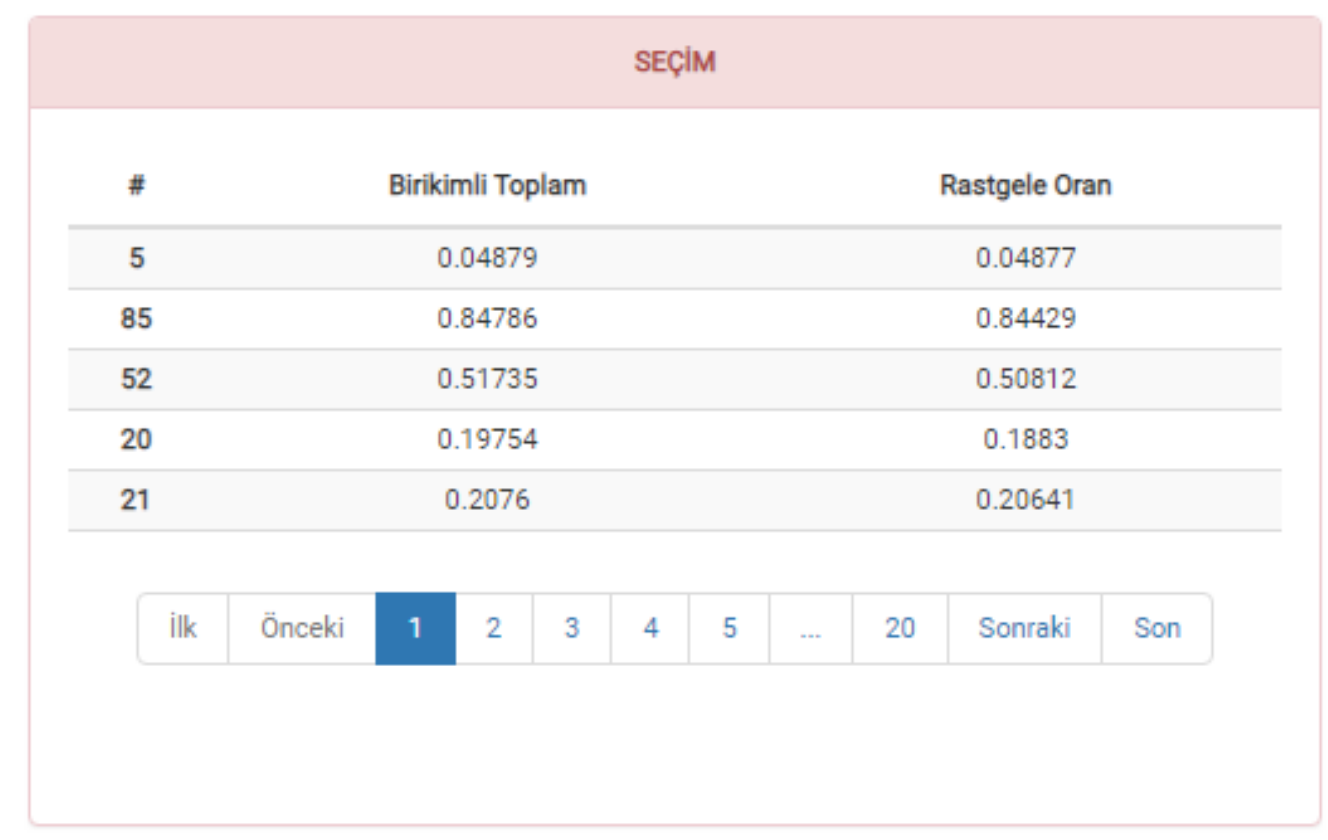

Şekil 13. Seçim işleminin geliştirilen yazılımdaki ara yüz görseli

Eskişehir Halk Ekmek İşletmesi için olası 100 adet çözüm içinden belli bir oranda rastgele olarak seçilen araç güzergâhları ikili olarak eşleştirilir. Seçilen çaprazlama tekniğinin uygulanmasıyla eşleşen araç güzergâhları ile yeni araç güzergâhları oluşturulur.

Mutasyon:

Bu çalışmada, mutasyon işlemi sırasında yer değiştirme tekniği kullanılmaktadır. Rasgele olarak seçilen herhangi iki noktanın (genin) birbiri ile yer değiştirilmesiyle uygulanır.

Literatürde yapılan çalışmalardan yararlanılarak bu çalışma kapsamında, genel kabul edilen oranlar tercih edilerek popülasyon büyüklügü 100 , çaprazlama oranı 0,60 ve mutasyon oranı 0,01 olarak kullanılmaktadır ve bu değerler tüm uygulama boyunca sabit tutulmaktadır.

Çaprazlama oranı x popülasyon büyüklüğü kadar birey çaprazlama işlemi sonucunda oluşturulur. Mutasyon işlemi için de benzer şekildedir. Mutasyon oranı x popülasyon büyüklüğü kadar birey mutasyona uğratılmaktadır.

\section{Sonlandırma kriteri}

Sonlandırma kriteri kullanıcının tercihlerine göre değişiklik gösterebilir. Çalışma kapsamında, sonlandırma kriteri olarak maksimum yineleme sayısı belirlenmiştir ve işleyiş sürecinde durdurma işlemi yapılmadığı takdirde genetik algoritma bu sayıya ulaşıncaya kadar devam eder. Ele alınan problemde maksimum nesil sayısı 2000 olarak belirlenmiştir. Bu değer, genetik algoritma adımlarının kaç kez tekrarlanacağını ifade etmektedir. 
Belirlenen maksimum yineleme sayısı kadar tekrarlanan nesil oluşturma işlemlerinden sonra bulunan minimum mesafeye sahip birey, optimizasyon probleminin çözümü kabul edilmiştir.

\section{Analiz Sonuçları}

Ele alınan problem için genetik algoritma 2000 kez çalıştırılmıştır ve yaklaşık olarak 25 saniye (sn) gibi kısa bir sürede sonuca ulaşılmıştır. Genetik algoritma ile belirlenen araç rotalama işlemi sonucunda Eskişehir Halk Ekmek İşletmesi'nin mevcut olarak kullandığı rotasyon iyileştirilerek daha iyi bir sonuç elde edilmesi sağlanmıştır.

Çalışma öncesinde, Eskişehir Halk Ekmek İşletmesi rotalarının oluşturulmasında 17 yıllık tecrübesinden yararlanarak 3 aracın toplam kat ettiği mesafeyi 236,54 km olarak belirlediği görülmektedir. Genetik algoritma ile hesaplama sonucunda ise 3 aracın toplam kat ettiği mesafe 210,24 km olarak hesaplanmıştır. Bu durumda, günlük olarak hesaplanan değerde 26,3 km'lik bir iyileşme sağlanmaktadır.

Bir günlük siparişlere göre belirlenen rotalama işleminin ayın diğer günleri içinde aynı olacağı düşünüldüğünde, Eskişehir Halk Ekmek İşletmesi'nin mevcut kullanmakta olduğu rotasyona göre aylık olarak yaklaşı 790 km'lik bir farkla iyileşme görülmektedir. Bu durumda, işletmenin hem maliyet hem zaman olarak kar etmesini sağlamaktadır. Maliyet bazında bakıldığında, kullanılan araçlar şehir içinde gidilen her km'de ortalama 1,6 TL/lt yakıt harcamaktadır ve aylık olarak düşünüldügünde işletme için 1.264 TL'lik bir yakıt tasarrufu ile maliyette azalma sağlanmaktadır.

Eskişehir Halk Ekmek İşletmesi'nin kullanmakta olduğu mevcut rota ve genetik algoritma ile çözüm sonucu oluşturulan rota arasındaki karşılaştırılmanın yapılabilmesi amacıyla Tablo 3. ve Tablo 4. ile araçların rotasyonları gösterilmektedir. Tablo 3.3.'te işletmenin üretim tesisinden çıkan 1. Araç ilk olarak 39 numaralı noktaya uğramaktadır, daha sonra 40 numaralı noktaya geçmektedir. Bu şekilde tüm satış büfelerine uğrayarak rotasında bulunan tüm satış büfelerinin talebini karşıladıktan sonra tekrar üretim tesisine dönmektedir. 1. Araç için üretim tesisi ve satış büfeleri arasındaki mesafe tablonun ikinci sütununda verilmektedir. Üretim tesisi ile 39 numaralı satış büfesinin arasındaki mesafe $10 \mathrm{~km}, 39$ numaralı ve 40 numaralı satış büfesi arasındaki mesafe $0,6 \mathrm{~km}$ şeklindedir. En alt satırda ise tüm araçların toplam rota mesafesi 236,54 km olarak görülmektedir. Tablo 4.'te benzer şekilde bilgiler içermektedir. 
Tablo 2. Eskişehir Halk Ekmek İşletmesi’nin kullandığı mevcut rota

\begin{tabular}{|c|c|c|c|c|c|}
\hline \multicolumn{2}{|l|}{ 1. Araç } & \multicolumn{2}{|c|}{ 2. Araç } & \multicolumn{2}{|l|}{ 3. Araç } \\
\hline Rota & $\begin{array}{l}\text { Mesafe } \\
(\mathrm{km})\end{array}$ & Rota & $\begin{array}{l}\text { Mesafe } \\
(\mathrm{km})\end{array}$ & Rota & $\begin{array}{l}\text { Mesafe } \\
(\mathrm{km})\end{array}$ \\
\hline 1 (Üretim Tesisi) & & 1 (Üretim Tesisi) & & 1 (Üretim Tesisi) & \\
\hline 39 (Takkal1-1) & 10 & 27 (Hava Has.) & 2,8 & 13 (Derman) & 2,1 \\
\hline 40 (Takkal1-29 & 0,6 & 33 (Savaș) & 0,7 & 22 (Fevziçakmak-1) & 2,9 \\
\hline 2 (71 Evler-1) & 5,3 & 45 (Vişnelik) & 2,3 & 23 (Fevziçakmak-2) & 0,9 \\
\hline 3 (71 Evler-2) & 0,04 & 25 (Göztepe) & 1,3 & 21 (Esentepe) & 5 \\
\hline 1 (Üretim Tesisi) & 11,3 & 1 (Üretim Tesisi) & 5,8 & 48 (Yeşiltepe-1) & 1 \\
\hline 35 (Sultandere-1) & 17,1 & 7 (Büyükdere) & 8,6 & 49 (Yeşiltepe-2) & 0,5 \\
\hline 20 (Ertaş) & 9 & 26 (Gültepe) & 0,7 & 1 (Üretim Tesisi) & 3,9 \\
\hline 17 (Emek-4) & 1,1 & 47 (Yenikent) & 0,8 & 51 (Yunustepe) & 3,7 \\
\hline 16 (Emek-3) & 1 & 1 (Üretim Tesisi) & 5,8 & 38 (Sirintepe) & 0,6 \\
\hline 1 (Üretim Tesisi) & 11,3 & 36 (Şahintepesi) & 15,5 & 52 (Zincirlikuyu) & 1,5 \\
\hline 15 (Emek-2) & 10,5 & 42 (Toki-3) & 0,6 & 41 (Tepebaş1) & 1,5 \\
\hline 43 (Toki-5) & 2,7 & 12 (Çankaya) & 1,1 & 1 (Üretim Tesisi) & 2,8 \\
\hline 19 (Erenköy-1) & 0,5 & 30 (Odunpazarı) & 4,1 & 44 (Uluönder) & 3,8 \\
\hline 46 (Yenidoğan-1) & 1 & 29 (Kurtuluş) & 1,2 & 8 (Çamlıca-1) & 2,3 \\
\hline 1 (Üretim Tesisi) & 8,4 & 50 (Yimpaş) & 0,8 & 14 (Elmali) & 0,9 \\
\hline 24 (Gökmeydan-2) & 8,6 & 1 (Üretim Tesisi) & 4 & 9 (Çamlıca-2) & 0,7 \\
\hline 18 (Emeksiz) & 3,4 & 31 (Opera) & 2,8 & 10 (Çamlica-3) & 0,5 \\
\hline 37 Şarhöyük) & 7,5 & 28 (Kırım) & 1 & 1 (Üretim Tesisi) & 6,5 \\
\hline 1 (Üretim Tesisi) & 4 & 4 (Bağlar) & 1,6 & 11 (Çamlıca-4) & 5,7 \\
\hline & & 32 (Ömerağa) & 1,5 & 6 (Batıkent-2) & 3,4 \\
\hline & & 1 (Üretim Tesisi) & 2 & 5 (Batıkent) & 1,9 \\
\hline & & & & 34 (Sihhiye) & 4,9 \\
\hline & & & & 1 (Üretim Tesisi) & 1,2 \\
\hline Toplam Mesafe & 113,34 & Toplam Mesafe & 65 & Toplam Mesafe & 58,2 \\
\hline
\end{tabular}

Kullanılan mevcut rotada araçların kat ettiği mesafelerde iyi bir dağılım olmadığı görülmektedir. Taşıma kapasitesi sık sık yeniden doldurulduğu için yakın veya uzak fark etmeksizin her seferinde üretim tesisine dönüş yapılmaktadır. Genetik algoritma ile bulunan çözümde araçların kat ettiği mesafelerde her araca km bazında uygun bir dağılım yapılması sağlanmaktadır. 
Tablo 2. Genetik Algoritma ile Çözüm Sonucu Oluşturulan Optimum Rota

\begin{tabular}{|c|c|c|c|c|c|}
\hline \multicolumn{2}{|l|}{ 1. Araç } & \multicolumn{2}{|l|}{ 2. Araç } & \multicolumn{2}{|c|}{ 3. Araç } \\
\hline Rota & $\begin{array}{l}\text { Mesafe } \\
(\mathrm{km})\end{array}$ & Rota & $\begin{array}{l}\text { Mesafe } \\
(\mathrm{km})\end{array}$ & Rota & $\begin{array}{l}\text { Mesafe } \\
(\mathrm{km})\end{array}$ \\
\hline 1 (Üretim Tesisi) & & 1 (Üretim Tesisi) & & 1 (Üretim Tesisi) & \\
\hline 41 (Tepebaşı) & 2,8 & 28 (K1rım) & 2,1 & 27 (Hava Has.) & 2,8 \\
\hline 44 (Uluönder) & 0,8 & 24 (Gökmeydan-2) & 3,2 & 47 (Yenikent) & 2,9 \\
\hline 8 (Çamlica-1) & 2,3 & 36 (Şahintepesi) & 4,3 & 26 (Gültepe) & 0,8 \\
\hline 14 (Elmali) & 0,9 & 16 (Emek-3) & 2,8 & 1 (Üretim Tesisi) & 6,1 \\
\hline 1 (Üretim Tesisi) & 6,1 & 12 (Çankaya) & 1,8 & 34 (S1hhiye) & 1,2 \\
\hline 51 (Yusuntepe) & 3,7 & 42 (Toki-3) & 1,1 & 33 (Savaş) & 3,8 \\
\hline 38 (Şirintepe) & 0,6 & $43($ Toki-5) & 1,4 & 25 (Göztepe) & 1,6 \\
\hline 49 (Yessiltepe-2) & 1,1 & 1 (Üretim Tesisi) & 7 & 7 (Büyükdere) & 1 \\
\hline 48 (Yeşiltepe-1) & 0,5 & 30 (Odunpazarı) & 4,1 & 45 (Vişnelik) & 2 \\
\hline 1 (Üretim Tesisi) & 3,4 & 46 (Yenidoğan-1) & 2,8 & 1 (Üretim Tesisi) & 3,7 \\
\hline 39 (Takkal1-1) & 10 & 50 (Yimpaş) & 3,1 & $17($ Emek-4) & 10,7 \\
\hline 3 (71 Evler-2) & 3,9 & 29 (Kurtuluş) & 0,8 & 15 (Emek-2) & 1,3 \\
\hline $2(71$ Evler-1) & 0,04 & 1 (Üretim Tesisi) & 3,6 & 18 (Emeksiz) & 1,3 \\
\hline 35 (Sultandere-1) & 7,1 & 32 (Ömerağa) & 2 & 1 (Üretim Tesisi) & 9,1 \\
\hline 1 (Üretim Tesisi) & 17,1 & 40 (Takkal1-2) & 9,3 & 52 (Zincirlikuyu) & 5,9 \\
\hline 21 (Esentepe) & 2,6 & 20 (Ertaş) & 4,2 & 5 (Batıkent) & 1,5 \\
\hline 22 (Fevziçakmak-1) & 4,2 & 19 (Eranköy-1) & 2 & 11 (Çamlıca-4) & 1,8 \\
\hline 23 (Fevziçakmak-2) & 0,9 & 1 (Üretim Tesisi) & 9,1 & 9 (Çamlıca-2) & 0,9 \\
\hline 31 (Opera) & 3,2 & & & 10 (Çamlıca-3) & 0,5 \\
\hline 37 (Şarhöyük) & 1,6 & & & 6 (Batıkent-2) & 3,4 \\
\hline 13 (Derman) & 1,3 & & & 1 (Üretim Tesisi) & 7 \\
\hline 4 (Bağlar) & 1,6 & & & & \\
\hline 1 (Üretim Tesisi) & 0,5 & & & & \\
\hline Toplam Mesafe & 76,24 & Toplam Mesafe & 64,7 & Toplam Mesafe & 69,3 \\
\hline
\end{tabular}

İşletmenin kullandığı mevcut rota ve genetik algoritma ile bulunan rota karşılaştırıldığında bir günlük verilerden yararlanılarak oluşturulan rota planlamasında sağlanan iyileşme \%11 gibi oldukça önemli bir değerdir. Aylık olarak düşünüldüğünde bu oran ile elde edilebilecek iyileşme işletme maliyetleri açısından oldukça önemli olmaktadır.

\section{Sonuç ve Öneriler}

Eskişehir Halk Ekmek İşletmesi ekmek dağıtımı için, araçların büfelere en kısa güzergâhtan rotalanması üzerine genetik algoritma ile çözümü gerçekleştirecek web ortamında çalışacak bir uygulama yazılmıştır ve mevcut araç rota planlaması iyileştirilmeye çalışılmıştır. Sonrasında mevcut ve önerilen sistemlerde araç rotalarının karşılaştırılması yapılmıştır.

Geliştirilen yazılımda genetik algoritma 2000 kez çalıştırılmıştır ve yaklaşık olarak 25 saniye (sn) gibi kısa bir sürede sonuca ulaşılmıştır. İşletmenin bir günlük sipariş miktarı kullanılarak yapılan çalışmada, mevcut sistemde 3 aracın toplam kat ettiği mesafe 236,54 km olarak hesaplanırken, genetik algoritma ile çözüm sonucunda bu mesafe 210,24 km olarak hesaplanmaktadır. Bu durumda, günlük olarak hesaplanan değerde 26,3 km'lik bir iyileşme sağlanmaktadır. Aylık olarak düşünüldüğünde, bir ay için yaklaşık olarak 790 km'lik bir iyileşme sağlanmıştır. Maliyet bazında bakıldığında, kullanılan araçlar şehir içinde gidilen her km'de ortalama 1,6 TL/lt yakıt harcamaktadır ve aylık olarak düşünüldüğünde işletme için 
1.264 TL'lik bir yakıt tasarrufu ile maliyette azalma sağlanmaktadır. Bu çalışma sonucunda işletmeye ait 51 adet satı̧s büfesi için tüm talepleri karşılayacak bir rotasyon oluşturularak araçlarının hem zamandan tasarruf etmesini hem de maliyetin düşürülmesini sağlayan bir çözüm sunulmuştur.

Araçların rotasyon dağılımına bakıldığında, mevcut sistemde 1. Aracın rotası 113,34 km, 2. Aracın rotası $65 \mathrm{~km}$ ve 3. Aracın rotası 58,2 km'dir. Araçlar arasında km bazında dengeli bir dağılım sağlanamamıştır. Diğer yandan genetik algoritma ile elde edilen çözümde 1 . Aracın rotas $16,24 \mathrm{~km}, 2$. Aracın rotas $164,7 \mathrm{~km}$ ve 3 . Aracın rotas $169,3 \mathrm{~km}$ olarak hesaplanmaktadır. Genetik algoritma ile elde edilen çözümün araç rotasyonlarında km bazında kısmen dengeli bir dağılım sağlanmaktadır.

Çalışmada ele alınan işletme, satış büfeleri dışında kurumlara da hizmet vermektedir. Bu nedenle geliştirilen bilgisayar sisteminin daha geniş boyutta kullanımı da mümkündür. Bunların yanında geliştirilen sistemin benzer problemlerle karşılaşılan başka işletmeler tarafından da kullanılabilecek esneklikte olduğu düşünülmektedir.

\section{Kaynakça}

Acar, E. (2014). Yatırım problemlerinin değerlendirilmesinde evrimsel algoritma kullanımı yap işlet devret modeli altyapı projesi üzerine bir uygulama (Tez Numarası. 357356). [Doktora Tezi. Eskişehir: Anadolu Üniversitesi Sosyal Bilimler Enstitüsü]. YÖK Tez Merkezi.

Chen, T. \& Chen, C., (1997). Improvements of simple genetic algorithm in structural desing. International. Journal for Numerical Methods in Engineering, 40, 1323-1334.

Christofides, N., (1976). The vehicle routing problem. Recherche Operationnelle, 10 (2), 55-70.

Çeyrekoğlu, S., (2017). Araç rotalama problemine genetik algortima yaklaşımı ve örnek bir uygulama (Tez Numarası. 461711).[Yüksek Lisans Tezi. İstanbul: İstanbul Üniversitesi Fen Bilimleri Enstitüsü]. YÖK Tez Merkezi.

Çolak, S., (2010). Genetik algoritmalar yardımı ile gezgin satıcı probleminin çözümü üzerine bir uygulama. Çukurova Üniversitesi Sosyal Bilimler Enstitüsü Dergisi, 19 (3), 423-438.

Dasgupta, D. \& Michalewicz, Z., (1997). Evolutionary algorithmsin engineering applications, Germany: Springer.

Demircioğlu, M., (2009). Araç rotalama probleminin sezgisel bir yaklaşım ile çözümlenmesi üzerine bir uygulama (Tez Numarası. 241435). [Doktora Tezi. Adana: Çukurova Üniversitesi Sosyal bilimler Enstitüsü]. YÖK Tez Merkezi.

Dreo, J., Siarry, P., Petrowski, A., \& Taillard, E., (2006). Metaheuristics for hard optimization. Germany:Springer-Verlag, 978-3-540-23022-9.

Duman, C., (2007). Genetik algoritma ile tesis yerleşimi tasarımı ve bir uygulama (Tez Numarası.213245). [Yüksek Lisans Tezi. İstanbul: Yıldız Teknik Üniversitesi Fen Bilimleri Enstitüsü.]. YÖK Tez Merkezi.

Düzakın, E. ve Demircioğlu, M., (2009). Araç rotalama problemleri ve çözüm yöntemleri. Çukurova Üniversitesi İIBBF Dergisi, 13 (1), 68-87. 
Eksioglu, B., Vural, A.V. \& Reisman, A., (2009). The vehicle routing problem: A taxonomicreview. Computers \& Industrial Engineering, 57, 1472-1483.

Elmas, Ç., (2007). Yapay zeka uygulamaları, Ankara: Seçkin.

Emel, G.G., ve Taşkın, Ç., (2002). Genetik algoritmalar ve uygulama alanları. Bursa: Uludăg Üniversitesi İktisadi ve İdari Bilimler Fakültesi Dergisi, XXI (1), 129-152.

Er, H., Çetin, M. ve İpekçi Çetin, E. (2005). Finansta evrimsel algoritmik yaklaşımlar: Genetik algoritma uygulamaları. Akdeniz İ.I. B.F. Dergisi, 10, 73-94.

Fisher, M. L. \& Jaikumar, R., (1981). Ageneralized assignment heuristic for vehicle routing, Networks, 11, 109-124.

Gomez, P. A. \& Hougen, D. F., (2007). Initial population for genetic algorithms: A metric approach. International Conference on Genetic and Evolutionary Methods. LasVegas, Nevada, USA, 25-28 Haziran.

Gupta, S.M. \& Imtanavanich, P. (2010). Evolutionary computational approach for disassembly sequencing in a multiproduct environment. Biomedical Soft Computing and Human Sciences. 15 (1), 71-76.

Günay, N.S. (2013). Genetik algoritma ile araç rotalama problemlerinin çözümü için görsel rotalama yazılımı geliştirme (Tez Numarası. 337103). [Yüksek Lisans Tezi. İstanbul: İstanbul Üniversitesi Fen Bilimleri Enstitüsü.]. YÖK Tez Merkezi.

Haupt, R. L. \& Haupt, S.E. (2004). Practical genetic algorithms (Second Edition), New Jersey: John Wiley\&Sons.

Karaova, M., Smarkov, V. \& Penev, S. (2005). Genetic operators crossover and mutation in solving the TSP problem. International Conference on Computer Systemsand Technologies - CompSysTech, - IIIA (20), 1-6.

Keskintürk, T., Topuk, N. ve Özyeşil, O. (2015). Araç rotalama problemleri ile çözüm yöntemlerinin sınıflandırılması ve bir uygulama. İşletme Bilimi Dergisi, 3 (2), 77-107.

Kırda, K., (2013). Evsel ilaç atıklarının toplanması projesindeki tersine lojistik sürecinin modellenmesi için genetik algoritmaların kullanılması (Tez Numarası. 337587). [Doktora Tezi. İzmir: Dokuz Eylül Üniversitesi Sosyal Bilimler Enstitüsü]. YÖK Tez Merkezi.

Koza, J. R., (1998). Genetic Programming: On the programming of computers by means of natural selection. London: The MIT Press, 0-262-11170-5.

Özkan, B., (2008). Dinamik gezgin satıcı probleminin çözümü için bir eniyileme kütüphanesinin tasarımı ve görsel yazılım geliştirme ortamı ile birlikte gerçekleştirimi (Tez Numarası. 216130). [Yüksek Lisans Tezi. İzmir: Ege Üniversitesi Fen Bilimleri Enstitüsü]. YÖK Tez Merkezi.

Öztürk, A. (2011). Yöneylem araştırması. Bursa: Ekin.

Rothlauf, F., (2006). Representations for genetic and evolutionary algorithms. Springer-Verlag, Netherlands, 978-3-540-25059-3.

Sivanandam, S.N. \& Deepa, S.N., (2008). Introduction to genetic algorithms. Berlin: Springer Science\& Business Media.

Şen, Z., (2004). Genetik algoritmalar ve eniyileme yöntemleri. İstanbul: Su Vakfı.

Toth, P. \& Vigo, D., (2002a). Models, relaxations and rxact approaches for the capacitated vehicle routing problem. Discrete Applied Mathematics 123, 487 - 512.

Yücel, A., (2016). Mesafe kısıtlı çok yönlü kümelenmiş açık araç rotalama probleminin genetik algoritma ile çözümü. (Tez Numarası.465573). [Doktora Tezi. İstanbul: İstanbul Üniversitesi Sosyal bilimler Enstitüsü]. YÖK Tez Merkezi. 